
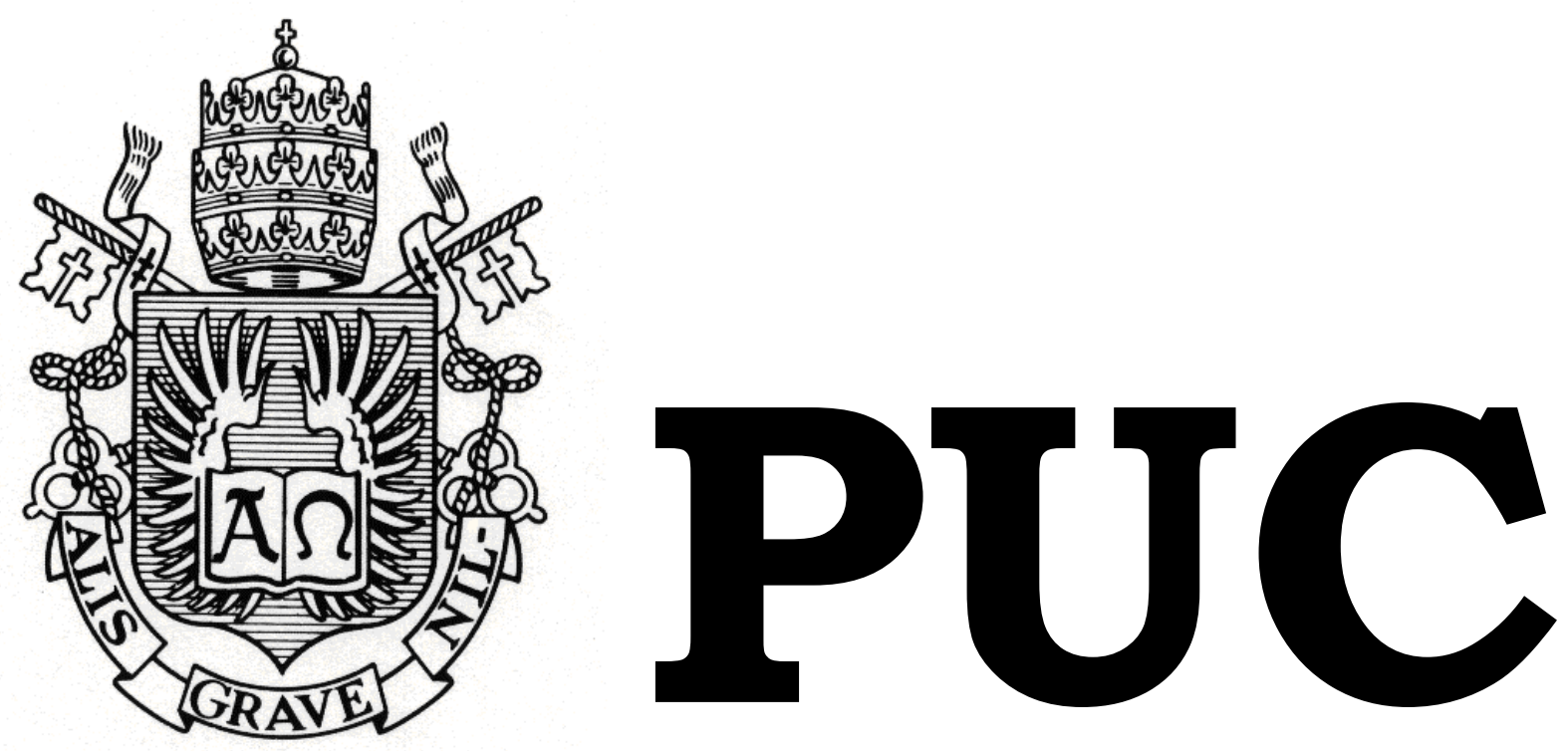

DEPARTAMENTO DE DIREITO

\title{
O PROCESSO DE JUDICIALIZAÇÃO DAS POLÍTICAS PÚBLICAS SOCIAIS COMO GARANTIA DE UM ESTADO DEMOCRÁTICO DE DIREITO
}

por

JÚLIA DE BRITO LOPES

ORIENTADORA: Regina Coeli Lisbôa Soares

2017.2

PONTIFÍCIA UNIVERSIDADE CATÓLICA DO RIO DE JANEIRO RUA MARQUÊS DE SÃO VICENTE, 225 - CEP 22453-900 RIO DE JANEIRO - BRASIL 


\section{O PROCESSO DE JUDICIALIZAÇÃO DAS POLÍTICAS PÚBLICAS SOCIAIS COMO GARANTIA DE UM ESTADO DEMOCRÁTICO DE DIREITO}

por

JÚLIA DE BRITO LOPES

Monografia apresentada ao Departamento de Direito da Pontificia Universidade Católica do Rio de Janeiro (PUC-Rio) como requisito parcial para a obtenção do Título de Bacharel em Direito.

Orientador: Regina Coeli Lisbôa Soares 
Nós, representantes do povo brasileiro, reunidos em Assembleia Nacional Constituinte para instituir um Estado Democrático, destinado a assegurar o exercício dos direitos sociais e individuais, a liberdade, a segurança, o bem-estar, o desenvolvimento, a igualdade e a justiça como valores supremos de uma sociedade fraterna, pluralista e sem preconceitos, fundada na harmonia social e comprometida, na ordem interna e internacional, com a solução pacífica das controvérsias, promulgamos, sob a proteção de Deus, a seguinte CONSTITUIÇÃO DA REPÚBLICA FEDERATIVA DO BRASIL. (Preâmbulo da 


\section{AGRADECIMENTOS}

Primeiramente, agradeço a Deus por sempre ter me abençoado e guiado em todas as etapas da minha vida, agora com um anjo a mais ao seu lado. Vô, obrigada pelas eternas lembranças que coleciono de minha infância e adolescência, tão amorosas, como só você soube fazer. Obrigada por participar, mesmo que aí em cima, de mais uma conquista de sua neta.

Obrigada aos meus familiares, que me proporcionam uma educação de qualidade e acreditam no meu potencial, deixando minha vida mais leve. Sem vocês, mãe, pai e vó, eu não conseguiria. Pai, obrigada por me encorajar em cada escolha que faço. Você, com muito amor e dedicação aos seus filhos, não mede esforços para realizar nossos sonhos.

Agradeço também a todos os professores que me acompanharam durante a graduação, em especial à minha orientadora, professora Regina, que, de maneira muito carinhosa, iluminou meus pensamentos para desenvolver este trabalho. Agradeço ao professor Peixinho, que, em um momento de angústia, estendeu-me a mão e, confiando em meu potencial, ajudou-me a concluir esse curso.

Tão importante quanto, agradeço ao meu mentor na iniciação da minha vida profissional, Gilberto Clóvis. Com todo o carinho, recebeume como estagiária em seu espaço de trabalho e me ensinou, junto com a sua equipe, muito além do que o Direito poderia me ensinar. A sua determinação e o seu senso de justiça me inspiram nessa nova fase que irei traçar em minha vida.

Aos meus amigos, Bernardo Graber e Flávia Leite, que fazem parte dessa equipe e sempre tiveram muita paciência comigo, alegrando minhas semanas por quase três anos, mesmo em momentos de angústia. 
Obrigada por serem, de forma tão genuína, mais do que colegas de trabalho. Admiração é mais do que sinto por vocês.

Obrigada Pierre, por não ter sido só o meu vizinho. Obrigada por ser meu mentor, meu mais querido amigo, por quem tenho muita adoração e carinho.

Por fim, agradeço aos amigos que fiz durante a faculdade, com os quais dividi tantas alegrias e momentos inesquecíveis. Vocês tornaram essa trajetória mais feliz.

Sou grata a todos vocês. 


\section{RESUMO}

Lopes, Júlia de Brito. O processo de judicialização das políticas públicas sociais como garantia de um estado democrático de direito. Monografia (Graduação em Direito) - Pontifícia Universidade Católica do Rio de Janeiro: Rio de Janeiro, 2017.

O presente trabalho tem por objeto o estudo do processo de judicialização das políticas públicas, mais especificadamente em relação as políticas sociais, decorrentes da falta de garantia por parte do Estado brasileiro do direito à educação e à saúde aos seus indivíduos, direitos fundamentais de segunda dimensão, positivados na Constituição vigente. Inicialmente, buscase contextualizar como esses direitos foram incorporados nas constituições contemporâneas, por meio do movimento chamado de Neoconstitucionalismo, que trouxe normas embebidas em valores axiológicos, dotadas de força normativa e eficácia. Assim, os princípios que norteiam o Direito e suas normas programáticas são impositivos e de observância obrigatória pelos governantes, não sendo toleráveis alegações por parte do Poder Público de falta de investimento nesses setores por carência de verba orçamentária, haja vista que essas áreas devem ser priorizadas em um Estado Democrático de Direito. Devendo, portanto, o Poder Judiciário, quando provocado, dirimir em favor da população que tem seus direitos violados, não significando desrespeito ao princípio da separação dos três poderes.

Palavras Chaves: Judicialização das políticas sociais - Direitos fundamentais - Saúde - Educação - Constituição dirigente - Normas programáticas - Eficácia - Separação dos Poderes - Reserva do possível Mínimo existencial. 


\section{SUMÁRIO}

INTRODUÇÃO ...............................................................................................................

I. A SUPREMACIA DA CONSTITUIÇÃO .................................................................11

I.I. ENSAIO HISTÓRICO DO MOVIMENTO DE CONSTITUCIONALISMO .......11

I.II. BREVE ANÁLISE ACERCA DA TEORIA DA CONSTITUIÇÃO DE KONRAD HESSE ................................................................................................ 14

I.III. A CONSTITUIÇÃO BRASILEIRA COMO NORMA SUPREMA E SUA CLASSIFICAÇÃ̃ …………………………………………………………..... 16

II. A EFICÁCIA DAS NORMAS CONSTITUCIONAIS PROGRAMÁTICAS ......18

II.I. NORMAS CONSTITUCIONAIS SELF-EXECUTING E NOT SELF-EXECUTING E A REPERCUSSÃO DOUTRINÁRIA DO TEMA NO BRASIL ............................... 18

II.II. A CLASSIFICAÇÃO DE JOSÉ AFONSO DA SILVA E POSIÇÃO DOUTRINÁRIA DE DIRLEY DA CUNHA JR. FRENTE A EFICÁCIA JURÍDICA DAS NORMAS CONSTITUCIONAIS PROGRAMÁTICAS ..................................20

III. OS PRINCÍPIOS CONSTITUCIONAIS ............................................................31

III.I. O MÉTODO HERMENÊUTICO-CONCRETIZADOR E OS PRINCÍPIOS DE INTERPRETAÇÃO DA CONSTITUIÇÃO................................................................. 31

III.II. PRINCÍPIOS FUNDAMENTAIS DE ORGANIZAÇÃO DO ESTADO............33 III.III. CONCEITO, FUNÇÃO E CARACTERÍSTICAS DOS DIREITOS

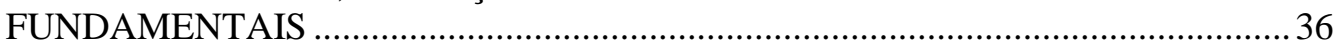

III.IV. OS DIREITOS FUNDAMENTAIS DE SEGUNDA DIMENSÃO E O

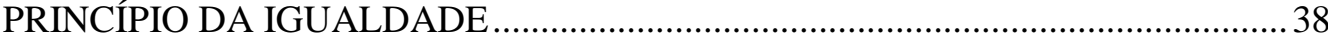

IV. O DIREITO SOCIAL À SAÚDE ...............................................................................42

V. O DIREITO SOCIAL À EDUCAÇÃO ...................................................................49

VI. A IMPOSSIBILIDADE DE APLICAÇÃO DA TEORIA DA RESERVA DO POSSÍVEL DIANTE DA DOUTRINA DO MÍNIMO EXISTENCIAL E O CONTEXTO SÓCIO-ECONÔMICO BRASILEIRO....................................................59

VI.I ORIGEM E ANÁLISE DA TEORIA DA RESERVA DO POSSÍVEL ................59

VI.II A DOUTRINA DO MÍNIMO EXISTENCIAL .....................................................65

VI.III A NÃO APLICAÇÃO DA TEORIA DA RESERVA DO POSSÍVEL PELA JURISPRUDÊNCIA DOS TRIBUNAIS BRASILEIROS, QUANDO HOUVER PREJUÍZO OU LIMITAÇÃO DO NÚCLEO BÁSICO DOS DIREITOS QUE COMPÕEM O MÍNIMO EXISTENCIAL .................................................................. 69

VII. CONCLUSÃO:..................................................................................................... 74

REFERÊNCIAS BIBLIOGRÁFICAS ...........................................................................76

CASOS APRESENTADOS À BANCA NA DEFESA........................................................80 


\section{INTRODUÇÃO}

Nasce o neoconstitucionalismo. Esse novo Direito constitucional contemporâneo rompe com a ideia de uma sociedade de classes, em que o povo é feito para servir ao Estado, ente imerso em Poder. Surge, assim, com a finalidade preponderante de colocar o homem e seus anseios em evidência e conferir efetividade à dignidade da pessoa humana, ponto central da Constituição. Em consequência, a Lei Maior passa a estabelecer condutas a serem observadas e cumpridas para os órgãos de direção política, bem como impõe proibições e obrigações, tanto para os direitos civis quanto para os direitos sociais, muitas vezes por meio de suas normas programáticas.

São incorporados novos valores e novas diretrizes à política, que prestigiam as dimensões de direitos fundamentais e do bem-estar social. Há uma maior necessidade de se pensar em um direito cada vez mais valorado em preceitos sociais, que trata de normas comprometidas com a dignidade da pessoa humana, a partir da regulamentação de uma vida em busca da garantia do mínimo existencial para cada indivíduo.

Dessa forma, são levantadas questões como direitos fundamentais, a Justiça Social, supremacia constitucional, eficácia jurídica das normas programáticas, princípios de interpretação constitucional, reserva do possível, o mínimo existencial e o processo de judicialização da realização de tais programas de governo direcionados à sociedade, principalmente em relação à garantia da educação e da saúde, de modo a se chegar à conclusão de que a efetividade dos direitos sociais é imprescindível ao Estado Democrático de Direito e, na hipótese de omissão dos Poderes Legislativo e Executivo, deverá o Poder Judiciário intervir para concretizá-los.

Frisa-se a abordagem acerca das novas demandas sociais a que o Estado brasileiro deve estar adstrito, consubstanciado nos direitos 
fundamentais sociais que compõe o núcleo essencial do mínimo existencial, direitos estes postos em uma Constituição dirigente, por meio também de normas dotadas de eficácia, diante da supremacia da constituição, que não podem ser aniquilados pela Teoria da reserva do possível ou pelo Princípio da separação dos Poderes.

Ressalta-se que o rol de direitos em destaque é trivial a qualquer sociedade que queira se desenvolver e diminuir os índices de analfabetismo, desigualdade social e mortalidade precoce. Isso porque, existe a necessidade de se deixar evidente que as normas programáticas, sobretudo as que tratam de direitos sociais, são impositivas de deveres a serem concretizados pelo Poder Público, caso contrário, trariam apenas sugestões e não normas que estabelecem uma diretriz aos governantes, um dever-ser. E como fazer essa mudança de forma jurídica?

Em relação ao Brasil, a população é demasiadamente carente quando se trata de acesso à educação e saúde. Infelizmente, são numerosas as pessoas que compõem as classes sociais mais baixas e que, por consequências, não desfrutam de um ensino de qualidade ou do tratamento médico necessário. Esse contexto reflete a má administração do Estado e a falta de interesse por meio dos governantes, representantes do povo, em investir e fomentar tais setores essenciais à dignidade da pessoa humana em seu mínimo existencial.

Diante da omissão do Poder Legislativo e do Poder Executivo, está o indivíduo à frente de violações de direitos subjetivos e chega-se à conclusão de que a judicialização de políticas públicas é imprescindível para a garantia dos direitos fundamentais e do exercício da democracia. A intervenção do Poder Judiciário se faz necessária sempre que algum cidadão, sujeito de direito, se encontrar impossibilitado de exercer prerrogativas inerentes ao cidadão, positivadas no ordenamento jurídico como direitos fundamentais.

A alegação, por parte do Estado, de que não há verba orçamentária suficiente não deve bastar para negar à sua população os direitos triviais do 
indivíduo que, em troca de sua liberdade, adere ao pacto social em nome do bem comum. Quando isso ocorre, deve haver a intervenção do Poder Judiciário, com a finalidade exclusiva de concretizar a Lei, impositiva e imperiosa, sempre que provocado, ao se deparar com a violação de direitos, principalmente quando essa violação se tratar de direitos fundamentais.

Nesse sentido, percebe-se que o processo de judicialização das políticas públicas promove um significativo deslocamento do poder da esfera do Legislativo e do Executivo para o Judiciário, que não deve ser ignorada e sequer tão criticada como tem ocorrido. Ora, o Poder Judiciário nada mais faz do que concretizar a vontade da Constituição e compelir o Estado a fornecer aos seus indivíduos o tratamento que lhes é garantido constitucionalmente.

É imprescindível que se tenha como propósito a força normativa da Lei Maior, norma suprema, em consonância com o Princípio da conformidade dos atos do poder público com a Constituição, sem o qual só haverá o retrocesso das conquistas sociais, diante da presença de órgãos políticos inoperantes e omissos. Isso, aliás, não pode ocorrer, haja vista o princípio da vedação ao retrocesso em relação aos direitos fundamentais. Afinal, o propósito de todo Estado Democrático de Direito é servir o seu povo e não o contrário.

Busca-se, por meio deste trabalho, mostrar que a Constituição, dotada de supremacia, é munida de normas que possuem em seu conteúdo eficácia e que refletem os anseios pela resolução das demandas sociais de sua época, de modo que não se pode admitir que o Estado seja ineficiente quanto às necessidades de seu povo, que busca mudanças. 


\section{A SUPREMACIA DA CONSTITUIÇÃO}

\section{I.I. ENSAIO HISTÓRICO DO MOVIMENTO DE CONSTITUCIONALISMO}

A importância de uma nova visão acerca do Direito Constitucional se faz imprescindível para aferir as transformações de ideais políticos e sociais ao longo dos séculos, em uma sociedade que está em constante processo de mutação. Com o surgimento do movimento denominado de Constitucionalismo, que emergiu com o propósito de reagir ao poder arbitrário dos governantes do Estado em busca de uma organização política, há uma valorização do conjunto de normas supremas, emanadas de forma indireta pelo povo, que definem a organização fundamental do Estado e da sociedade com o objetivo de limita-lo.

Se, em dado momento, a sociedade foi submetida a um governo autoritário e ilegítimo, atualmente, e graças às revoluções liberais do século XVIII, essa mesma sociedade passou e ainda passa por uma nova Era de limitação do poder e de declarações de direitos intrínsecos a ela. Invertem-se os valores e o Estado passa a ser criado para servir à sua comunidade, finalidade primordial de sua origem, não o oposto.

Os acontecimentos tenebrosos e desumanos do Pós-Segunda Guerra Mundial foram primordiais para essa mudança de paradigma. Principalmente no que diz respeito a visão do indivíduo como membro e criador de uma sociedade, o pós-guerra levou pensadores jurídicos, filósofos, cientistas sociais e políticos e juristas a analisar o Direito valorado em preceitos morais, éticos e filosóficos, com o objetivo de romper com o antigo imaginário de um Direito estabelecido pela ciência do Positivismo Jurídico e a Teoria Pura do Direito. Não se podia mais apoiar uma ciência do Direito empírica pura e simplesmente, que deu embasamento para o holocausto e a formação de governos totalitários como o nazismo e o fascismo.

Dessa forma, elucida Daniel Sarmento: 
Até a Segunda Guerra Mundial, prevalecia no velho continente uma cultura jurídica essencialmente legicêntrica, que tratava a lei editada pelo parlamento como a fonte principal - quase como a fonte exclusiva - do Direito, e não atribuía força normativa às constituições. (...) Os direitos fundamentais valiam apenas na medida em que fossem protegidos pelas leis, e não envolviam, em geral, garantias contra o arbítrio ou descaso das maiorias políticas instaladas nos parlamentos. Aliás, durante a maior parte do tempo, as maiorias parlamentares nem mesmo representavam todo o povo, já que o sufrágio universal só foi conquistado no curso do século XX.

(...) A percepção de que as maiorias políticas podem perpetrar ou acumpliciar-se com a barbárie, como ocorrera no nazismo alemão, levou as novas constituições a criarem ou fortalecerem a jurisdição constitucional, instituindo mecanismos potentes de proteção dos direitos fundamentais mesmo em face do legislador. ${ }^{1}$

Nesse sentido, os acontecimentos do século XX originaram na Europa uma nova fase acerca do pensamento constitucional, de modo que as sociedades seguintes herdaram a preponderância pelo reconhecimento da supremacia material e axiológica da Constituição. Essa nova percepção trouxe um conteúdo constitucional arraigado em preceitos éticos e morais, dotado de força normativa, que passou a irradiar sobre o direito vigente e a condicionar a sua validade. O neoconstitucionalismo, nesse contexto, veio para proporcionar a transição para o Estado Constitucional de Direito.

Dessa forma, o novo paradigma jurídico trouxe a compreensão de Constituição como norma jurídica fundamental, suprema, que impõe a força normativa dos princípios a ela intrínsecos, que irradiam para todo o ordenamento. Trata-se da lei em seu sentido mais amplo. Assim, não mais se admite a prevalência somente da Lei e do Princípio da Legalidade, únicas fontes que legitimavam os ordenamentos jurídicos até então vigentes.

Ao reconhecer a força normativa de princípios revestidos de elevada carga axiológica, como dignidade da pessoa humana, igualdade, Estado Democrático de

\footnotetext{
${ }^{1}$ Sarmento, Daniel. Artigo: O Neoconstitucionalismo no Brasil: riscos e possibilidades. 2009. p. 2.
} 
Direito e solidariedade social, o neoconstitucionalismo abre as portas do Direito para o debate moral. ${ }^{2}$

Diante deste panorama, no Brasil, se promulgou a Constituição Cidadã de 1988 e foi inserida, a tempo, uma maior conscientização acerca dos direitos constitucionais sociais que enunciam metas, finalidades e programas de ação a serem concretizados pelo Estado em conjunto com a sociedade. Como consequência desse constitucionalismo social, é indispensável à garantia da dignidade da pessoa humana e a instituição de uma linha norteadora à concretização de tais programas, de modo que o individuo deve exigir do Estado prestações positivas, de ordem econômica, social e cultural, necessárias à solução das demandas sociais.

Ao enxergar a Constituição contemporânea como instrumento de direção e efetivação de políticas públicas, introduzidas por meio de suas normas programáticas vinculativas a todos os Poderes - conceito de uma Constituição Dirigente - nos deparamos, ao sair do plano teórico, com a falta de efetivação de tais dispositivos pelo Poder Público, apesar de se estar diante de uma constituição nominal, conforme classificação ontológica desenvolvida por Karl Loewenstein ${ }^{3}$.

É essencial que se preserve a força normativa da Constituição, consoante Konrad $\mathrm{Hesse}^{4}$, para que haja a garantia desses direitos fundamentais, nos quais se respaldam os objetivos intrínsecos do Estado, principalmente diante de um país tão carente como o Brasil. Afinal, tais mudanças surgiram com o objetivo de submeter o Estado brasileiro a uma democracia material, comprometida com a Justiça Social.

\footnotetext{
${ }^{2}$ Sarmento, Daniel. Op. cit. p. 4.

${ }^{3}$ LOEWENSTEIN, Karl. Teoria de la Constitución. 2. ed. Barcelona: Ariel, 1976, p. 218

${ }^{4}$ Hesse, Konrad. A força normativa da constituição. Trad. de Gilmar Ferreira Mendes. 1991. Porto Alegre. Sérgio Antõnio Fabris Editor.
} 


\section{I.II. BREVE ANÁLISE ACERCA DA TEORIA DA CONSTITUIÇÃO DE KONRAD HESSE}

Considerada uma das Teorias da Constituição de maior relevância, a Teoria de Konrad Hesse compreende a Constituição Federal como a ordem jurídica fundamental da sociedade, que expressa a vontade de Constituição, uma vez que não se limita, tão somente, a ordenar de forma jurídica o Estado, mas principalmente por abraçar a ordenação da comunidade a que se insere, por meio de uma Constituição Jurídica e não apenas uma Constituição Real.

(...) "Constituição real" e "Constituição jurídica" estão em uma relação de coordenação. Elas condicionam-se mutuamente, mas não dependem, pura e simplesmente, uma da outra. Ainda que não de forma absoluta, a Constituição jurídica tem significado próprio. Sua pretensão de eficácia apresenta-se como elemento autônomo no campo de forças do qual resulta a realidade do Estado. A Constituição adquire força normativa na medida em que logra realizar essa pretensão de eficácia. ${ }^{5}$

Por meio dessa teoria, a Constituição, dotada de força normativa, tem como objetivos primordiais consagrar os princípios fundamentais que harmonizam e estabelecem uma unidade política, regulamentar o processo de solução de conflitos dentro de uma sociedade, organizar o exercício da função pública, definir os fundamentos e princípios da ordem jurídica e normatizar as relações econômicas.

Diante de tantas funções, a Constituição Federal é classificada como ordem jurídica material aberta, já que apresenta em seu conteúdo normas que possuem como característica a indeterminação, justamente para que haja a possibilidade de novas interpretações face ao quadro axiológico que a compõe. O que não quer dizer que a Constituição não possui força normativa, ao invés, apresenta como escopo nortear a realidade da comunidade sobre a

\footnotetext{
${ }^{5}$ HESSE, Konrad. Op. cit. p. 15-16.
} 
qual possui ingerência, de modo a garantir as liberdades sociais em um ambiente democrático.

A vontade da Constituição, assim, segundo o autor, nasce de três vertentes:

(...) Baseia-se na compreensão da necessidade e do valor de uma ordem normativa inquebrável, que proteja o Estado contra o arbítrio desmedido e disforme. Reside, igualmente, na compreensão de que essa ordem constitu[ida é mais do que uma ordem legitimada pelos fatos (e que, por isso, necessita de estar em constante processo de legitimação). Assenta-se também na consciência de que, ao contrário do que se dá com a lei do pensamento, essa ordem não logra ser eficaz sem o concurso da vontade humana. Essa ordem adquire e mantém sua vigência através de atos de vontade. ${ }^{6}$

Nesse sentido, essa vontade de Constituição tem como finalidade afastar o poder arbitrário e instituir uma ordem legítima, realizada por meio de atos de vontade dos participantes do processo constitucional, traduzida na força ativa da vontade humana sobre a Lei Fundamental. Não é admissível, como se observa na história, que o poder se sobreponha às normas jurídicas. Aliás, é o que determina a concepção cultural da Constituição, pois a norma constitucional não tem existência autônoma da realidade que institui e deve ser verificada em comparação com as condições históricas, sociais, econômicas de seu processo de realização.

Determinada pela realidade social e, ao mesmo tempo, determinante em relação a ela, não se pode definir como fundamental nem a pura normatividade, nem a simples eficácia das condições sócio-políticas e econômicas. A força condicionante da realidade e a normatividade da Constituição podem ser diferenciadas; elas não podem, todavia, ser definitivamente separadas ou confundidas. ${ }^{7}$

${ }^{6}$ HESSE, Konrad. Op. cit. p. 19-20.

${ }^{7}$ HESSE, Konrad. Op. cit. p. 15. 


\section{I.III. A CONSTITUIÇÃO BRASILEIRA COMO NORMA SUPREMA E SUA CLASSIFICAÇÃO}

Primeiramente, é necessário abordar o complexo de conteúdos estudados pelo Direito que são determinantes para o entendimento da Constituição como norma suprema.

Ao estudar a classificação das constituições, vê-se que a Constituição brasileira de 1.988 é caracterizada por ser uma constituição rígida quanto à sua origem e dirigente quanto à sua finalidade.

É rígida, pois apresenta elevado grau de formalidades para que haja qualquer alteração em seu conteúdo. Estabelece procedimentos especiais, solenes e formais que são indispensáveis e geram obstáculos à modificação de suas normas. Em relação à sua finalidade, a Constituição é dirigente ou programática, já que determina programas de ação que devem ser efetivados pelos órgãos estatais no âmbito social, econômico e cultural.

Como corolário da rigidez constitucional, o Princípio da Supremacia da Constituição estabelece a hierarquia das normas constitucionais sobre as demais normas do ordenamento jurídico, de modo a condicionar o fundamento último de validade desse arcabouço normativo.

O poder constituinte se eleva face aos poderes constituídos.

Percebe-se, então, que as normas constitucionais têm força imperativa e suprema. Kelsen, em sua obra "A Teoria Pura do Direito", já apresentava uma ordenação das normas jurídicas, de modo a hierarquizá-las. O jurista posiciona a Constituição no topo de seu triângulo normativo, de maneira mais elevada, uma vez que a Norma Fundamental confere validade as demais e as legitima.

\footnotetext{
${ }^{8}$ KELSEN, Hans. Teoria Pura do Direito, p.11. 1998. Martins Fontes Editora.
} 
Logo, por meio dessa teoria, o Direito é um complexo normativo prescritivo de condutas impostas aos indivíduos, um dever ser dotado de unicidade, já que todas as normas que ele abrange têm o mesmo fundamento de validade representado por essa norma fundamental.

Outro ponto de relevância para o estudo é o Princípio da Conformidade dos Atos do Poder Público com a Constituição, estabelecido por Gomes Canotilho9. Significa, de maneira sucinta, que deve haver necessariamente a exigência de uma correspondência entre os atos normativos do Poder Público, exteriorizados por meio da atuação estatal, com as regras e princípios da Constituição, dotados de posição hierárquica superior.

Contudo, se houver contraposição material ou formal entre os atos do Poder Público e a Constituição Federal, aqueles não podem exercer qualquer regulamentação na sociedade, posto que inconstitucionais.

Portanto, a Constituição irradia princípios e valores para fundamentar e validar as normas jurídicas que compõem a essência do ordenamento. Não há dúvidas de que a supremacia constitucional, consubstanciada na hierarquia normativa, existe quando todos os Poderes do Estado se encontram vinculados aos dispositivos da Constituição e são obrigados, impositivamente, a realizar as condutas determinadas por ela.

Isso decorre, exclusivamente, do fato de se condicionar o Estado à vontade soberano do povo, que detém a titularidade plena do poder constituinte e assim escolheu ser governado.

\footnotetext{
${ }^{9}$ CANOTILHO, José Joaquim Gomes. Direito Constitucional e Teoria da Constituição. Almedina. $7^{\mathrm{a}}$ Ed. 1993. p. 826
} 


\section{A EFICÁCIA DAS NORMAS CONSTITUCIONAIS PROGRAMÁTICAS}

\section{II.I. NORMAS CONSTITUCIONAIS SELF-EXECUTING E NOT SELF- EXECUTING E A REPERCUSSÃO DOUTRINÁRIA DO TEMA NO BRASIL}

Leciona Hans Kelsen que deve haver a distinção entre validade e eficácia da norma. A validade pertence ao “dever-ser", enquanto que a sua eficácia está na ordem do "ser" 10 . Busca-se mostrar que nada adiantaria a vigência da norma, que corresponde a sua validade, se a mesma não for eficaz, aplicável no plano dos fatos, tendo em vista que o mínimo de eficácia deverá ser condição de sua validade.

Atualmente, explana Maria Helena Diniz ao definir eficácia como a qualidade do texto normativo vigente de produzir, ou irradiar, no seio da coletividade, efeitos jurídicos concretos (...) e vai além, ao sustentar que não só a questão de sua condição técnica de aplicação, observância, ou não, pelas pessoas a quem se dirige, mas também a sua adequação em face da realidade social, por ele disciplinada, e aos valores vigentes na sociedade, o que conduziria ao seu sucesso. ${ }^{11}$

A par disso, pode-se observar a distinção entre eficácia social e eficácia jurídica. Enquanto aquela, tratada por Kelsen, está consubstanciada na verdadeira efetivação da norma, de modo que ela seja obedecida e aplicada à sociedade, esta, de interesse do Direito, consiste na capacidade jurídica de atingir os fins para os quais foi criada, em observância à vontade do legislador.

Dito isto, passa-se ao breve estudo da doutrina norte americana que dispõe sobre as normas constitucionais self-executing e not self-executing, as

\footnotetext{
${ }^{10}$ KELSEN, Hans. Op. cit. p.11.

${ }^{11}$ DINIZ, Maria Helena, Norma constitucional e seus efeitos. Editora Saraiva. 2009. p. 30
} 
normas autoaplicáveis ou auto executáveis e as normas não autoaplicáveis ou não auto executáveis.

As normas constitucionais self-executing devem ser aplicadas de imediato, já que têm como qualidade a plena eficácia jurídica. Já as normas not self-executing não dispõem dessa característica, uma vez que são dependentes de lei que as integrem. O tema, no Brasil, foi trazido à baila por Ruy Barbosa.

De forma sucinta, explica-se que, para que sejam normas selfexecuting, deve haver a aptidão para gerar os efeitos jurídicos que têm como fim desde o momento de sua vigência, são, assim, completas por si só; ao passo que as normas constitucionais not self-executing dependem da atuação do Poder Legislativo, por estarem incompletas e inaptas a produzirem efeitos desde logo, de modo a haver uma restrição quanto a sua força normativa vinculante ${ }^{12}$.

Pontes de Miranda, aliás, trata do mesmo tema, mas com nomenclatura diversa ao aduzir que há normas bastante em si e não bastante em si, a depender de regulamentação, ou não, para a aplicação destas, nesta ordem. O jurista reconhece que existem normas constitucionais programáticas que limitam a atuação do legislador, pois conferem visibilidade e têm como fundamento o projeto social da Constituição para a sociedade a que regulam.

\footnotetext{
${ }^{12}$ JR. Dirley da Cunha, Curso de Direito Constitucional. p. 136. $9^{\mathrm{a}}$ Ed. Editora Juspodvim
} 


\section{II.II. A CLASSIFICAÇÃO DE JOSÉ AFONSO DA SILVA E POSIÇÃO DOUTRINÁRIA DE DIRLEY DA CUNHA JR. FRENTE A EFICÁCIA JURÍDICA DAS NORMAS CONSTITUCIONAIS PROGRAMÁTICAS}

O Professor José Afonso defende a inexistência de qualquer norma destituída de eficácia. Contudo, distinguem-se quanto ao grau de seus efeitos jurídicos ${ }^{13}$.

Ao partir da classificação da doutrina italiana de Vezio Crisafulli, o doutrinador mineiro acrescenta um novo grupo. Assim, há normas constitucionais de eficácia plena, normas constitucionais de eficácia contida e normas constitucionais de eficácia limitada ou reduzida, subclassificada em normas de princípio institutivo (ou organizativo) e normas de princípio programáticas.

O enfoque do presente trabalho está adstrito à eficácia das normas programáticas. Contudo, explicita-se, de maneira breve, a classificação.

As normas constitucionais de eficácia plena, ao entrar em vigor, dispõem de aplicabilidade direta, imediata e integral, sendo as matérias que regulam dotadas de normatividade. Apesar de a matéria não ser pacífica quanto a tais mandamentos, entende Dirley da Cunha Jr. ${ }^{14}$ que as normas de eficácia plena são contempladas pelas normas definidoras de direitos e garantias, conforme determina o art. $5^{\circ}, \S 1^{\circ}$, da $\mathrm{CF}$ :

As normas definidoras dos direitos e garantias fundamentais têm aplicação imediata.

Ao fazer um paralelo com o explanado pela doutrina americana, conclui-se que as normas constitucionais de eficácia plena são normas selfexecuting.

\footnotetext{
${ }^{13}$ SILVA, José Afonso da. Aplicabilidade das normas constitucionais. Editora Malheiros. $8^{\mathrm{a}}$ Ed. 2.012

${ }^{14}$ JR. Dirley da Cunha. Op. cit. p. 140
} 
As normas constitucionais de eficácia contida têm aplicação imediata, que não depende de uma atuação do Poder Legislativo - embora previsto esse agir - mas mantém sua eficácia contida a certos limites, de modo que tais leis integrativas, quando editadas, reduzem a eficácia das normas em destaque. Além de lei posterior, também pode haver conceitos indeterminados que as restrinjam. Possuem, assim, aplicabilidade direta, imediata, mas não integral, uma vez que estão sujeitas a certas limitações.

As normas constitucionais de eficácia limitada ou reduzida dependem, para produzirem seus efeitos e serem eficazes, da atuação do Poder Legislativo, haja vista que a Constituição não conferiu a devida normatividade para tal. São de aplicação mediata, pois se submetem à lei que regulará, quando editada, seus limites. São, assim, de aplicabilidade mediata, indireta e reduzida.

Como dito, as normas constitucionais de eficácia limitada subdividem-se em normas constitucionais de princípio institutivo e normas constitucionais de princípio programático. As primeiras, o autor conceitua como aquelas através das quais o legislador constituinte traça esquemas gerais de estruturação e atribuições de órgãos, entidades ou institutos, para que o legislador ordinário os estruture em definitivo, mediante le $i^{15}$, já as segundas revelam um compromisso entre as forças políticas liberais e tradicionais e as reinvindicações populares de justiça social ${ }^{16}$.

De fato, as normas programáticas ensejam para a doutrina contemporânea muita divergência no que se refere à sua aplicabilidade. Isso porque, por terem conteúdo diretivo e serem normas abertas, há quem duvide, de maneira equivocada, de sua qualidade jurídica.

O Princípio da Supremacia da Constituição, igualmente, estabelece a hierarquia das normas constitucionais sobre as demais normas do

\footnotetext{
${ }^{15}$ JR. Dirley da Cunha. Op. cit. p.126
}

${ }^{16}$ JR. Dirley da Cunha. Op. cit. p. 145 
ordenamento jurídico. Logo, interpretação de que as normas abertas não gozam de eficácia jurídica não deve prosperar, pois, como dito, a Constituição é norma que dispõe de força imperativa e suprema.

Em sua obra Curso de Direito Constitucional, Dirley da Cunha Jr. ${ }^{17}$, ao expor as classificações acerca das normas jurídicas constitucionais, afirma que todos os juristas partem da premissa de que tais normas gozam de eficácia, divergindo, tão somente, quanto ao grau de cada uma. Conclui, assim, que normas oriundas do constituinte têm aplicabilidade, por disporem da qualidade de eficácia.

Nesse sentido, alude que qualquer norma constitucional, intrinsicamente dotada de eficácia, seja qual for - limitada, contida ou plena -, deve ser aplicada pelo Poder Judiciário, ainda que não haja legislação posterior que lhe confira aplicabilidade, haja vista que tais normais são fontes de direitos subjetivos.

Dessa forma, por ser o objetivo da Constituição enlaçar suas normas à sociedade que regula, definindo um plano a ser seguido pelo Estado, as normas programáticas são aplicáveis de imediato e norteiam a tomada de decisão dos órgãos de Poder, principalmente em relação aos direitos fundamentais. Da mesma forma, devem ser aplicados de imediato aos direitos econômicos, sociais e a todas as normas de conteúdo programático.

É inegável que as normas de direitos sociais dependem de uma atuação positiva do Estado como seu garante para que sejam efetivas in totum. Esse agir, em especial do Poder Executivo e do Poder Legislativo, é de suma importância, mas a omissão não afasta a eficácia jurídica e vinculante que lhes é intrínseca.

\footnotetext{
${ }^{17}$ JR. Dirley da Cunha. Op. cit. p. 147
} 
Alude Vezio Crisafulli ${ }^{18}$, quanto às normas programáticas, que há situações subjetivas de vínculo ou de vantagem. Isso em razão de essas normas vincularem o legislador diante do Princípio da Supremacia da Constituição. A não observância por parte do Estado gera a invalidação do ato de exercício do Poder, já as omissões acarretam inconstitucionalidades, passíveis de controle pelo Poder Judiciário. A consequência não poderia ser diferente.

Canotilho, por sua vez, argumenta da mesma forma e afirma que, embora as normas programáticas tenham como característica serem abertas e indeterminadas, os Tribunais devem aplicá-las e concretizá-las como se normas de eficácia plena fossem ${ }^{19}$. Compartilham da mesma opinião Luiz Roberto Barroso ${ }^{20}$ e Celso Antônio Bandeira de Mello ${ }^{21}$.

Portanto, não há outra interpretação jurídica que não seja a de atentar que as normas constitucionais programáticas são providas sim de eficácia e, dessa forma, são fontes geradoras de direitos subjetivos para a sociedade, de modo que sejam assegurados a elas o mesmo tratamento conferido às demais normas constitucionais de eficácia plena.

A propósito, o Estado brasileiro, ao afirmar-se Estado Democrático de Direito, tem como base a Constituição Federal, que representa as reinvindicações da população pela justiça social, com a qual o Estado democrático de direito deve estar sempre em conformidade. Esta é a ideia de democracia substantiva ou material. Com efeito, pode-se confirmar que, havendo omissão dos Poderes Legislativo ou Executivo, órgãos de direção do país quanto à efetivação dos direitos sociais, é devido que o Poder Judiciário exerça o controle de constitucionalidade e legalidade sobre as

\footnotetext{
${ }^{18}$ CRIZAFULLI, Vezio Stato, popolo, governo - Illusioni e desilusioniconstituzionali, 1985. p.6467 (tradução livre)

${ }^{19}$ Canotilho, J. J. Gomes. Direito Constitucional e Teoria da Constituição, Almedina, 3 ed. p. 827

${ }^{20}$ BARROSO, Luís Roberto. O Direito Constitucional e a efetividade de suas normas: limites e possibilidade da Constituição brasileira. Editora Renovar. $8^{a}$ Ed. 2006. p. 106

${ }^{21}$ DE MELLO, Celso Antônio Bandeira. Eficácia das normas constitucionais sobre a Justiça Social, Revista de Direito Social n ${ }^{\circ}$ 7. p.252-255
} 
referidas omissões ou atuações incongruentes com o que preconiza a Constituição.

Não cabe à justiça vendar seus olhos face ao legislador ineficaz.

Colaciona-se, então, o pertinente acórdão do Tribunal de Justiça do Estado do Rio Grande do Sul, que elucida a notável aplicação do tema para o direito brasileiro, retirado do sítio eletrônico do Superior Tribunal de Justiça, ao julgar a demanda em sede de recurso:

AGRAVO DE INSTRUMENTO No 1.340 .049 - RS (2010/0141437-1) RELATOR: MINISTRO HUMBERTO MARTINS AGRAVANTE MUNICIPIO DE NOVO HAMBURGO PROCURADOR: REGINALDO PARNOW ENNES E OUTRO(S) AGRAVADO: VALDIR DE OLIVEIRA HOFFMEISTER ADVOGADO: ANA MARIZA DE MATTOS BARBOSA - DEFENSORA PÚBLICA E OUTROS INTERES.: ESTADO DO RIO GRANDE DO SUL ADMINISTRATIVO - FORNECIMENTO DE MEDICAMENTOS - FUNDAMENTAÇÃO DO ACÓRDÃO EMINENTEMENTE CONSTITUCIONAL - AGRAVO IMPROVIDO. DECISÃO. Vistos. Cuida-se de agravo de instrumento tirado pelo MUNICÍPIO DE NOVO HAMBURGO contra decisão que obstou a subida de recurso especial, em demanda relativa a fornecimento de medicamentos. Extrai-se dos autos que o ora agravante interpôs recurso especial, com fundamento no art. 105, inciso III, alíneas "a" e "c", da Constituição Federal, contra acórdão do Tribunal de Justiça do Estado do Rio Grande do Sul, que deu provimento à apelação do agravante, nos termos da seguinte ementa (fl. 250e):"APELAÇÃO CÍVEL.DIREITO À SAÚDE. AÇÃO ORDINÁRIA COM PEDIDO DE ANTECIPAÇÃO DE TUTELA. LEGITIMIDADE PASSIVA DO MUNICÍPIO. RESPONSABILIDADE SOLIDÁRIA DO PODER PÚBLICO. APLICAÇÃO IMEDIATA E INCONDICIONADA DE DISPOSITIVO CONSTITUCIONAL. HONORÁRIOS ADVOCATÍCIOS. CONDENAÇÃO DO ESTADO EM CAUSAS PATROCINADAS PELA 
DEFENSORIA PÚBLICA. DESCABIMENTO. VERBA HONORÁRIA. REDUÇÃO. DESCABIMENTO. Apelo do Município: Legitimidade passiva e mérito: $\mathbf{O}$ acesso às ações e serviços de saúde é universal e igualitário (CF - art. 196), do que deriva a responsabilidade solidária e linear dos entes federativos, como já assentou o Supremo Tribunal Federal (RE 195.192/RS- rel. Min. Marco Aurélio). A saúde, elevada à condição de direito social fundamental do homem, contido no art. $6^{\circ}$ da CF, declarado por seus artigos 196 e seguintes, é de aplicação imediata e incondicionada, nos termos do parágrafo $1^{\circ}$ do artigo $5^{\circ}$ da C. Federal, que dá ao indivíduo a possibilidade de exigir compulsoriamente as prestações asseguradas. $O$ artigo 196 da Constituição Federal não faz distinção entre os entes federados, de sorte que cada um e todos, indistintamente, são responsáveis pelas ações e serviços de saúde, sendo certo que a descentralização, mera técnica de gestão, não importa compartimentar sua prestação. Redução da verba honorária: Indevida a redução da verba honorária por implicar em desafeição à dignidade da advocacia e do advogado. Apelo do Estado: Honorários ao Fadep: Quando sucumbe o Estado em ações com assistência judiciária patrocinadas pela Defensoria Pública, não se justifica juridicamente imputar-lhe o pagamento da verba honorária. E não só porque o Defensor Público é pago pelo Estado para assistir os desamparados de recursos pecuniários, como porque o crédito e a dívida se reúnem na mesma pessoa - o crédito, do Fundo de Reaparelhamento; a dívida, do Estado a quem pertence o Fundo. DERAM PROVIMENTO AO APELO DO ESTADO E NEGARAM PROVIMENTO AO APELO DO MUNICÍPIO. UNÂNIME. "Alega o agravante, nas razões do recurso especial, violação do art. 198 da Constituição Federal e do art. $8^{\circ}$ da Lei n. 8.080/90. Aponta, ainda, divergência jurisprudencial. Sustenta que "a responsabilidade legal para o fornecimento do medicamento postulado, por não constar na relação de medicamentos da lista de atenção básica do Município é exclusiva do Estado do Rio Grande do Sul" (fl. 360e). Foram oferecidas contrarrazões (fls. 325/338e). Sobreveio o juízo de 
admissibilidade negativo na instância de origem (fls. 359/373e), o que ensejou a interposição do presente agravo. É, no essencial, o relatório.Consoante o disposto no art. 544, $\S 3^{\circ}$, primeira parte, do Código de Processo Civil, e atendidos os pressupostos de admissibilidade do agravo de instrumento, passo ao exame do recurso especial. Não merece prosperar o recurso. Impende assinalar que, embora a recorrente alegue ter ocorrido violação de matéria infraconstitucional, qual seja, do art. $8^{\circ}$ da Lei $n$. 8.080/90, segundo se observa dos fundamentos que serviram para a Corte de origem apreciar a controvérsia, o tema foi dirimido no âmbito constitucional, de modo a afastar a competência desta Corte Superior de Justiça para o deslinde do desiderato contido no recurso especial. Aliás, essa circunstância fica evidente consoante se observa da simples leitura do voto condutor do julgado recorrido, ao asseverar, em síntese, que (fls. 253/258e): "Somente agora o direito à saúde foi elevado à condição de direito social fundamental do homem, contido no artigo $6^{\circ}$ da Constituição que declara logo adiante, por seus artigos 196 e seguintes, ser "a saúde direito de todos e dever do Estado, garantido mediante políticas sociais e econômicas que visem à redução do risco de doença e de outros agravos e ao acesso universal e igualitário às ações e serviços para sua promoção e recuperação, serviços e ações que são de relevância pública". Pelo que se percebe do enunciado destes artigos da Constituição, trata-se de um direito que comporta duas vertentes, como ensinam Canotilho e Vital Moreira: "uma, de natureza negativa, que consiste no direito a exigir do Estado (ou de terceiros) que se abstenham de qualquer ato que prejudique a saúde; outra a de natureza positiva, que significa o direito a medidas e prestações estatais visando a prevenção das doenças e o tratamento delas" (Constituição da República Portuguesa Anotada - vol. 1/342/343).Por seu turno, JOSÉ AFONSO DA SILVA ensina: “A SAÚDE É CONCEBIDA COMO DIREITO DE TODOS E DEVER DO ESTADO, QUE ADEVE GARANTIR MEDIANTE POLÍTICAS SOCIAIS E ECONÔMICAS QUE VISEM À REDUÇÃO DO RISCO DE DOENÇA E 
DE OUTROS AGRAVOS. O DIREITO À SAÚDE REGE-SE PELOS PRINCÍPIOS DA UNIVERSALIDADE E DA IGUALDADE DE ACESSO ÀS AÇÕES E SERVIÇOS QUE A PROMOVEM, PROTEGEM E RECUPERAM" (Curso de Direito Constitucional Positivo - Malheiros Nona ed. pág. 707). Em causa a antiga e tormentosa questão da eficácia das normas constitucionais que desde o grande Ruy, a partir da Constituição de 1891, vem desafiando a doutrina e os Tribunais. Partindo dos grandes clássicos do direito constitucional norte americano, Ruy Barbosa acolheu a distinção entre normas autoaplicáveis e normas não-auto-aplicáveis (self-executing, sel-acting ou self-enforcing e notselexecuting, not self-acting, ou not self-enforcing). As primeiras, executáveis por si mesmas, seriam as que "não se haja mister de constituir ou designar uma autoridade, nem criar ou indicar um processo especial, e aquelas onde o direito instituído se ache armado, por si mesmo, pela sua própria natureza, dos meios de execução e preservação" (Ruy Barbosa - Comentários à Constituição Federal Brasileira - Saraiva - 1933 - vol. II, pág. 488). Acrescenta mais adiante o consagrado mestre que "uma disposição constitucional é executável por si mesma, quando, completa no que determina, lhe é supérfluo o auxílio supletivo da lei, para exprimir tudo o que intenta e realizar tudo o que exprime" (Ob. citada, pág. 492). Já as normas não auto-aplicáveis, segundo o mesmo autor, estariam a depender de uma ação do legislador para tornar-se efetivas porque "não revestem dos meios de ação essenciais ao seu exercício os direitos que outorgam, ou os encargos que impõe: estabelecem competências, atribuições, poderes, cujo uso tem de aguardar que a Legislatura, segundo o seu critério, os habilite a se exercerem" (Ob. citada, pág. 488/489). Pontes de Miranda, abeberandose nas lições de Ruy, seguiu seus passos no que respeita à classificação das normas constitucionais naqueles dois grupos. Reconheceu, porém, o que não fizera Ruy, a existência de normas programáticas atribuindo a estas grau de cogência tão-só para limitar a atividade do legislador 
infraconstitucional no sentido de não poder contrariar o programa estabelecido na Constituição (Comentários à Constituição de 1967 - Ed. Rev. dos Tribunais - 1970 - tomo I, pág. 127). Modernamente, temos a divisão proposta por JOSÉ AFONSO DA SILVA que pela primeira vez formulou teoria tridimensional da eficácia da norma constitucional. Segundo o consagrado publicista de São Paulo, as normas constitucionais podem ser divididas em três grupos: normas de eficácia plena, dotadas de aplicabilidade direta, imediata e integral, sem depender de intermediação legislativa, seja as que "desde a entrada em vigor da Constituição, produzem, ou têm possibilidade de produzir, todos os efeitos essenciais, relativamente aos interesses, comportamentos e situações, que o legislador constituinte, direta ou indiretamente, quis regular"; normas de eficácia contida, "aquelas em que o legislador constituinte regulou suficientemente os interesses relativos a determinada matéria, mas deixou margem à atuação restritiva por parte da competência discricionária do poder público, nos termos que a lei estabelecer ou nos termos de conceitos gerais nela enunciados"; por último as normas de eficácia limitada, que englobam as chamadas normas declaratórias de princípios programáticos, de aplicabilidade indireta e reduzida, por não terem recebido do legislador constitucional a normatividade suficiente para por si só gerarem seus efeitos, dependendo de intervenção legislativa. Como se percebe, a norma constitucional não faz depender sua eficácia e sua positivação à existência de recursos, à implementação de programas ou à edição de lei infraconstitucional. Assegura por si só a quem, comprovadamente carente, o direito subjetivo ao acesso universal e igualitário às ações e serviços de saúde para sua proteção e recuperação. Contém, por isso, elementos mínimos indispensáveis à sua aplicabilidade, a par de não ter o Constituinte expressamente remetido sua concreção ao legislador ordinário, pela clássica expressão "na forma da lei”. Como se vê, o dispositivo em causa tem razoável densidade normativa: define o objeto 
do direito - promoção, proteção e recuperação da saúde. Basta por isso, a meu sentir, comprovadas a moléstia e a carência, como no caso, para investir o particular do direito subjetivo à gratuidade assegurado no dispositivo constitucional invocado. Ademais disso, o direito à saúde e à assistência aos desamparados (artigo $6^{\circ}$ da $\mathrm{CF}$ ), intimamente vinculado ao direito à vida e ao princípio da dignidade da pessoa humana, é direito fundamental no sentido formal e material, de aplicação imediata e incondicionada, nos termos do parágrafo $1^{\circ}$ do artigo $5^{\circ}$ da C. Federal, sendo dada ao indivíduo a possibilidade de exigir compulsoriamente as prestações asseguradas nas normas constitucionais definidoras dos direitos fundamentais sociais. Como se vê, os serviços de saúde são de relevância pública e de responsabilidade do Poder Público, integrado em uma rede regionalizada e hierarquizada de ações e serviços federais, estaduais e municipais, o chamado Sistema Único de Saúde, que tem no polo ativo qualquer pessoa e por objeto o ATENDIMENTO INTEGRAL. De tal sorte, o Poder Público - federal, estadual ou municipal - é responsável pelas ações e serviços de saúde, não podendo, cada um e todos, esquivar-se do dever de prestá-los de forma integral eincondicional. A compensação que ocorrerá internamente entre os entes é questão que somente a eles diz respeito, não podendo atingir a pessoa que necessita do serviço de saúde, devendo o ente, acionado judicialmente, prestar o serviço e após, resolver essa interregulação. Por isso, não calha a alegação de ilegitimidade passiva. $\mathrm{O}$ acesso às ações e serviços de saúde é universal e igualitário (CF - art. 196), do que deriva a responsabilidade solidária e linear dosentes federativos, como já assentou o Supremo Tribunal Federal (RE 195.192/ RS- Rel. Min. Marco Aurélio)." Verifica-se, pois, que a Corte de origem analisou a matéria tão somente à luz do arts. $6^{\circ}$ e 196 da Constituição Federal. Assim, inviável o exame do pleito da recorrente, porquanto o instrumento utilizado não comporta esta análise. A competência do Superior Tribunal de Justiça referese à matéria infraconstitucional. A discussão sobre preceitos da Carta Maior cabe à Suprema Corte, ex vi do art. 102 da Constituição Federal. Ante o 
exposto, com fundamento no art. 557, caput, do CPC, nego provimento ao agravo de instrumento. Publique-se. Intimem-se. Brasília (DF), 24 de setembro de 2010. MINISTRO HUMBERTO MARTINS. Relator. (grifouse). 


\section{OS PRINCÍPIOS CONSTITUCIONAIS}

\section{III.I. O MÉTODO HERMENÊUTICO-CONCRETIZADOR E OS PRINCÍPIOS DE INTERPRETAÇÃO DA CONSTITUIÇÃO}

O Método hermenêutico-concretizador de interpretação constitucional, segundo Konrad Hesse ${ }^{22}$, se baseia na função fundamental do intérprete da norma jurídica, que é exercer uma atividade criativa de concretização da Constituição. O conteúdo da norma a que se chegará por meio dessa atividade interpretativa se relaciona com a realidade social, de modo que o julgador deve estar atento às circunstancias axiológicas daquele momento. Três pilares são imprescindíveis à interpretação constitucional: a Constituição Federal, a interpretação e o caso concreto.

Dessa forma, a tarefa hermenêutica se inicia através de um problema que, para ser solucionado pelo aplicador do direito, necessita que a interpretação formulada esteja intimamente relacionada ao que determina a Constituição. A atividade de concretização deve reproduzir um círculo hermenêutico entre os três pilares acima destacados, em um movimento de ir e vir, conforme salienta Gomes Canotilho ${ }^{23}$.

Dito isso, passa-se ao estudo dos princípios de interpretação constitucional, desenvolvidos a partir deste Método.

De acordo com Gomes Canotilho ${ }^{24}$, os princípios que auxiliam no processo de hermenêutica, dentre outros, são: o princípio da unidade da Constituição, o princípio do efeito integrador da Constituição, o princípio da máxima efetividade, o princípio da força normativa da Constituição e, por

\footnotetext{
${ }^{22}$ HESSE, Konrad. Elementos de Direito Constitucional da República Federal da Alemanha. Trad. Luís Afonso Heck, Porto Alegre. Sérgio Antônio Fabris, 1.998, p.63

${ }^{23}$ CANOTILHO, J. J. Gomes. Direito Constitucional e Teoria da Constituição. Almedina. $7^{a}$ Ed. 1993. p. 1.138

${ }^{24}$ CANOTILHO, J. J. Gomes. Op. cit., p. 1.148
} 
fim e tão relevante quanto os demais, o princípio da interpretação conforme a Constituição.

O princípio da unidade da constituição determina que se analise o ordenamento constitucional a partir de uma unidade, um sistema único, que não abre espaço para incongruências. Essa unidade normativa sistematizada não possui qualquer hierarquia entre suas normas jurídicas, já que todas decorrem da mesma fonte, a Constituição, e têm o mesmo fundamento de validade.

O princípio do efeito integrador significa que o intérprete da Constituição Federal deve estar em consonância com uma maior integração política e social, ou seja, a atividade interpretativa deve sempre buscar a adesão entre a sociedade e a política, temas sem os quais a Constituição não se sustenta.

O princípio da máxima efetividade indica que a interpretação deve ser a mais satisfatória e eficaz possível, de modo a arrancar do texto constitucional sua máxima efetividade, para que abranja todos os casos necessários ao deslinde da causa.

O princípio da força normativa da constituição, por sua vez, impõe que a Constituição seja dotada de força para vincular e impor suas determinações e sanções.

Por fim, o princípio da interpretação conforme a Constituição atende ao controle de constitucionalidade e se aplica quando a norma jurídica constitucional apresentar mais de um sentido possível. Estabelece que a interpretação mais adequada deve ser aquela que não contrarie o texto constitucional, diante da sua unidade e de sua sistematização, caso contrário, se estará diante de um caso de inconstitucionalidade. 


\section{III.II. PRINCÍPIOS FUNDAMENTAIS DE ORGANIZAÇÃO DO ESTADO}

Entre os princípios fundamentais escolhidos na Assembleia Constituinte e positivados na Constituição Federal de 1988, convém ressaltar aqueles que se referem à forma de Estado, à forma de Governo, ao regime político e à conexão entre os Poderes.

Todo o poder emana do povo, que o exerce por meio de representantes eleitos ou diretamente, nos termos desta Constituição $0^{25}$.

Primeiramente, observa-se o princípio republicano, que se apresenta já no nome deste país, República Federativa do Brasil, e que delimita a forma de governo adotada. O princípio em destaque traz como ponto essencial o modo como os governantes, representantes do povo, que exercem o poder por meio de mandatos eletivos temporários, em nome da sociedade, tratam da res publica. Tem por elemento a igualdade formal das pessoas, uma vez que é inadmissível qualquer tipo de discriminação entre pessoas de mesmas condições jurídicas. Essa forma de governo é adotada e exercida com responsabilidade, palavra chave que norteia a atuação dos governantes administrativa, civil e penalmente - pelos seus atos.

O princípio que se relaciona com a forma de Governo é o princípio do Estado democrático de direito, que soma em um só o princípio do Estado de Direito com o princípio do Estado Democrático. É de Direito porque deve se pautar na legalidade, na Lei. E é democrático porque tem como fundamento a soberania popular, que delega seu poder aos representantes. $\mathrm{O}$ ordenamento jurídico atual representa as reinvindicações do povo pela justiça social que, através de seus representantes, devem concretizar os valores democráticos da sociedade, com o qual o Estado Democrático de Direito deve estar sempre em conformidade.

\footnotetext{
${ }^{25}$ Artigo $1^{\circ}$, p.ú. da Constituição Federal de 1988
} 
O princípio fundamental da soberania popular é explicitado no texto constitucional por meio de seu art. $1^{\circ}$, parágrafo único ${ }^{26}$. De acordo com o que aduz o dispositivo, verifica-se que a Constituição Cidadã adota a forma de democracia representativa ao afirmar que o povo exerce o seu poder por meio de representantes que são eleitos pelo voto popular. Assim, ao votar, o povo exerce participação direta na escolha de seus representantes, que devem cumprir as propostas de governo que os levaram a representar seu eleitorado.

Tal princípio corporifica a soberania popular, exercida através do sufrágio universal, pelo voto direto e secreto, com valor igual para todos, mediante plebiscito, referendo e a iniciativa popular.

(...) Da conjugação da Democracia representativa e Democracia direta temos um modelo misto de Democracia semidireta, que nada mais é senão uma Democracia representativa com alguns institutos ou mecanismos de participação direta do povo na formação da vontade política nacional. Da Democracia semidireta se desenvolve a chamada Democracia participativa. ${ }^{27}$

Por fim, no que se refere ao princípio da separação dos poderes, observa-se que o Poder é essencial para regulamentar a conduta dos indivíduos que convivem em sociedade. Esse poder, que é uno e indivisível, manifesta-se através de determinadas funções estatais, que são as funções legislativa, executiva e judiciária. O que há, na verdade, é uma separação das funções de Estado, indispensável para que haja o controle do exercício do poder político pelos diversos órgãos que o compõem, mas que representam um só Poder.

Historicamente, é sabido que Montesquieu, após Locke, trouxe a ideia da separação do Estado em Três Poderes. Atualmente, esses Poderes correspondem as diferentes funções de Estado, realizadas, necessariamente,

\footnotetext{
${ }^{26}$ Todo o poder emana do povo, que o exerce por meio de representantes eleitos ou diretamente, nos termos desta Constituição.

${ }^{27}$ JR. Dirley da Cunha. Op. cit. p. 431.
} 
por órgãos distintos e especializados, independentes, harmônicos e de maneira equânime. Isto ocorre para que cada um dos Poderes tripartidos possa exercer suas funções típicas, sem haver qualquer usurpação de competências, e também coibir que qualquer um deles ultrapassem suas esferas de atuação. Trata-se da ideia recíproca de limitação dos poderes.

A função do Poder Legislativo consiste na atividade típica de legislar, formular regras gerais e abstratas que regulamentam a sociedade e o Estado e compõem o ordenamento jurídico, bem como na atividade de fiscalizar o cumprimento das leis. A atividade típica do Poder Executivo, por sua vez, é a atividade de Governo, que, segundo Maria Sylvia Z. Di Pietro é a atividade superior de planejar, dirigir, comandar, como a atividade subordinada de executar $^{28}$. Já a função típica do Poder Judiciário corresponde à função jurisdicional realizada pela atividade de guardar a Constituição com a aplicação da lei na administração e na resolução de conflitos.

Dessa forma, o princípio da separação dos Poderes tem por finalidade evitar que haja o exercício do Poder concentrado, para que seja respeitada a efetivação das garantias das liberdades públicas. A limitação, então, traz um sistema equilibrado de freios e contrapesos, que visa o controle mútuo do poder pelo próprio poder, concretizado por meio das funções atípicas, que são realizadas de forma módica, subsidiária, em que um Poder participa de maneira limitada de certas tarefas do outro Poder.

(...) o que se tem, deveras, é uma verdadeira coordenação ou colaboração ou coparticipação entre os Poderes em certas tarefas, onde um Poder participa, de forma limitada e secundária, da função de outro, que a conserva sua, ensejando um funcionamento harmônico ou uma colaboração recíproca, embora independente, na tarefa comum, tendo como objetivo o equilíbrio político, a limitação do Poder

\footnotetext{
${ }^{28}$ Di Pietro, Maria Sylvia Zanella. Direito Administrativo. 27. Ed. Atlas S.A. 2014
} 
e, em consequência, a proteção da liberdade e a melhor realização do bem comum $^{29}$.

Importante apresentar todos os princípios fundamentais em destaque, tendo em vista que, por tratarem da estrutura da máquina estatal e do vínculo entre o Estado e o povo, se irradiam sobre toda a regulamentação da relação entre Estado e sociedade, bem como no gerenciamento desse maquinário, de modo a limitar qualquer tipo de arbitrariedade e, por consequente, evitar qualquer inconstitucionalidade.

Ademais, frisa-se que todos são de extrema relevância, tendo em vista que um complementa o outro. Logo, são indispensáveis para a compreensão da noção dos elementos constitutivos do Estado e como eles se relacionam entre si.

\section{III.III. CONCEITO, FUNÇÃO E CARACTERÍSTICAS DOS DIREITOS FUNDAMENTAIS}

A expressão direitos fundamentais é utilizada pela Constituição Federal como gênero de todas as espécies de direitos. Estão compostos no Título II por meio dos capítulos I ao VII. São direitos humanos positivados na Constituição, que têm como critério o princípio da dignidade da pessoa humana, fundamento da República Federativa do Brasil, de modo que todos os demais direitos devem se reportar a este princípio máximo para que sejam qualificados como direitos fundamentais.

Como ressalva, tendo em vista o reconhecimento dos direitos fundamentais às pessoas jurídicas, o princípio da dignidade da pessoa humana não é critério exclusivo para a identificação de um direito como direito fundamental.

\footnotetext{
${ }^{29}$ JR. Dirley da Cunha. Op. cit. p.440.
} 
Dirley da Cunha Jr. conceitua os direitos fundamentais como posições jurídicas que investem o ser humano de um conjunto de prerrogativas, faculdades e instituições imprescindiveis a assegurar uma existência digna, livre, igual e fraterna de todas as pessoas ${ }^{30}$.

Importante analisar os direitos fundamentais como direitos que sofrem mutações. Devido a sua historicidade, esse gênero tem como idiossincrasia as transformações que passa ao longo do tempo, o que proporciona novas visões e a incorporação de novas demandas sociais, de acordo com o contexto histórico em que se situam, ampliando seus conceitos.

Os direitos fundamentais também possuem diversas funcionalidades, conforme se pode observar pela Teoria dos Quatro Status de Jellinek. A Teoria busca analisar as possíveis relações entre o indivíduo e o Estado que o compõe, a fim de posicioná-lo em condições jurídicas relevantes. Por fazer parte do espaço público, já que pertence à sua comunidade política e social, e também do seu espaço privado de atuação, a presente Teoria busca demonstrar com clareza o processo histórico de emancipação desse indivíduo tão oprimido pelo poder estatal.

Os status imprescindíveis a esse estudo são os status civitatis e o status activus. O primeiro confere aos cidadãos exigir do próprio Estado e das suas instituições estatais prestações positivas, que fomentam necessidades intrínsecas ao homem e à dignidade da pessoa humana. Já o segundo status proporciona a esse indivíduo a participação ativa da formação da vontade política, pois, repita-se, é membro da comunidade política do Estado a que pertence $^{31}$.

Não há como negar que os direitos fundamentais vinculam a todos e, inclusive, ao legislador.

\footnotetext{
${ }^{30}$ JR. Dirley da Cunha, Op. cit., p. 53

${ }^{31}$ LENZA, Pedro. Direito Constitucional Esquematizado. $18^{\circ}$ Ed. 2.004. Editora Saraiva. p. 1.063
} 
A função prestacional, por sua vez, é aquela que o indivíduo realiza por meio do Estado, para usufruir e gozar do fornecimento de necessidades básicas que somente as instituições estatais podem oferecer. Impõe que o Estado seja, portanto, atuante de maneira positiva, para que garanta os típicos direitos sociais.

Os Direitos fundamentais, a propósito, têm como características triviais a indivisibilidade, uma vez que integram um todo indivisível e existem em conjunto; a proibição do retrocesso, característica de extrema importância, em razão da sua evolução histórica; e a constitucionalização, já que os direitos humanos são inerentes ao homem, independentes de qualquer positivação necessária, para que se tornem efetivos.

O postulado da proibição ao retrocesso merece destaque principalmente no que se refere aos direitos sociais, uma vez que impossibilita a supressão ou diminuição das conquistas sociais, sob pena de incorrer em inconstitucionalidades. Tal postulado foi reconhecido por meio de cláusulas pétreas, inauguradas pela Constituição Cidadã, pois obstam qualquer redução dos Direitos e Garantias Fundamentais.

\section{III.IV. OS DIREITOS FUNDAMENTAIS DE SEGUNDA DIMENSÃO E O PRINCÍPIO DA IGUALDADE}

O princípio da igualdade, corolário dos direitos fundamentais de segunda dimensão, está intrinsecamente ligado à democracia, posto que não é compatível com qualquer tratamento desigual que não seja justificado com base nas diferenciações sociais, raciais e econômicas. Tais tratamentos diferenciados, contudo, devem ser usados apenas para tentar diminuir as desigualdades humanas. 
Luiz Roberto Barroso ${ }^{32}$ analisa as três dimensões da igualdade no mundo contemporâneo. São elas: a igualdade formal, a igualdade material e a igualdade como reconhecimento. Todas as dimensões se apresentam expressamente na Constituição Cidadã e não são independentes umas das outras. Ao contrário, afirma o jurista que a igualdade efetiva busca a igualdade perante a lei, a redistribuição de igualdades e o reconhecimento das igualdades.

Desse modo, elucida que a igualdade formal corresponde à proteção contra a existência de privilégios e tratamentos discriminatórios, conforme disposto na primeira parte do art. $5^{\circ}$ da Constituição, Todos são iguais perante a lei, sem distinção de qualquer natureza; a igualdade material, por sua vez, se consubstancia nas demandas por redistribuição de poder, riqueza e bem estar social, objetivo fundamental da República, disposto no art. $3^{\circ}$, inciso III, erradicar a pobreza e a marginalização e reduzir as desigualdades sociais e regionais; por fim, a igualdade como reconhecimento significa o respeito que se deve ter em relação às minorias, sua identidade e diferenças, sejam de cunho racial, religioso, sexual ou qualquer outra, também objetivo fundamental da República positivado no art. $3^{\circ}$, inciso IV, promover o bem de todos, sem preconceitos de origem, raça, sexo, cor, idade e quaisquer outras formas de discriminação.

A partir da queda do Estado Liberal, observa-se a importância da igualdade formal, ponto obrigatório de passagem na construção de uma sociedade democrática e justa ${ }^{33}$, uma vez que se fez necessário que esse novo Estado em formação satisfaça as necessidades coletivas. Para tanto, a dimensão da igualdade formal se projeta na igualdade perante a lei, que trata de um comando dirigido aos Poderes Executivo e Judiciário que a executam

\footnotetext{
32 BARROSO, Luís Roberto; OSÓRIO, Aline Rezende Peres. "Sabe com quem está falando?": Algumas notas sobre o princípio da igualdade no Brasil contemporâneo. Texto-base da apresentação no Seminário en Latinoamérica de Teoría Constitucional y Política" - SELA, ocorrido entre 11 e 14 de junho de 2014, organizado pela YALE Law School.

${ }^{33}$ BARROSO, Luís Roberto; OSÓRIO, Aline Rezende Peres. Op. cit. p. 5
} 
e aplicam, respectivamente, e na igualdade na lei, que deve ser observada pelo Poder Legislador ao elaborar o texto normativo.

Diante do colapso do Estado Liberal, ascendeu o Estado do Bem-Estar Social e, com ele, surgiram os chamados direitos sociais. A igualdade material, neste momento, ganha relevância, pois o Estado Social, atento às demandas da sociedade, tem como finalidade reduzir as desigualdades até então presentes. Para isso, são consagrados os direitos sociais, econômicos e culturais, direitos fundamentais de segunda dimensão.

O princípio da solidariedade é essencial à ideia de que todos são, de alguma maneira, responsáveis pelas carências dos indivíduos e minorias sociais. Passa-se, assim, a reconhecer esses direitos sociais como categoria jurídica que consubstancia o princípio da justiça social, efetivado através das políticas públicas, principalmente no âmbito da educação, saúde, geração de empregos e distribuição de renda.

Surge, desse modo, o direito à efetiva igualdade, protegido constitucionalmente, cuja finalidade é diminuir as desigualdades sociais, econômicas e qualquer outro modo de diferenciação negativa, de modo material e concreto, diante do forte apelo da sociedade mundial, mesmo que em níveis e em épocas diferentes.

Percebe-se, pois, que o direito à igualdade é gênero composto pelos direitos sociais, direitos econômicos e direitos culturais, que, novamente, por serem direitos de dimensão positiva, exigem uma prestação estatal de forma permanente, com o objetivo de garantir a todos o mínimo existencial.

Portanto, não há dúvidas de que tais direitos podem ser lesados tanto pela intervenção ilegal do Estado como pela omissão do poder público. 
São direitos sociais a educação, a saúde, a alimentação, o trabalho, a moradia, o transporte, o lazer, a segurança, a previdência social, a proteção à maternidade e à infância, a assistência aos desamparados, na forma desta Constituição. ${ }^{34}$

${ }^{34}$ Artigo $6^{\circ}$ da Constituição Federal de 1.988 


\section{O DIREITO SOCIAL À SAÚDE}

A saúde é direito de todos e dever do Estado, garantido mediante políticas sociais e econômicas que visem à redução do risco de doenças e de outros agravos e ao acesso universal e igualitário às ações e serviços para sua promoção, proteção e recuperação $0^{35}$.

O direito à saúde se encontra no rol de direito sociais da seguridade social. Abarca direitos que visam a garantia de um mínimo trivial a uma existência do indivíduo dotada de dignidade e, por isso, necessita da ação do Estado, criando para ele a obrigação de dispor de recursos orçamentários básicos e vitais à realização da Justiça social ${ }^{36}$. Observa-se que a garantia ao direito à saúde é estabelecida também em legislação infraconstitucional.

Aparece na Constituição Federal em diversos artigos, além dos já colacionados neste trabalho e apresenta-se, pois, como direito de todos e dever do Estado por meio de normas principiológicas, que geram direitos subjetivos aos indivíduos e obrigações a serem buscadas em comum e de forma solidária, pelos entes da federação, conforme dispõe o art. 23, inciso II, da Carta Magna ${ }^{37}$.

Importante perceber que, além de estar presente no rol de direitos sociais, o direito à saúde está ligado intrinsecamente à tutela da dignidade da pessoa humana, posto que mantém o bem jurídico mais precioso do nosso ordenamento, a vida. Não obstante, também é espécie que compõe o gênero dos direitos presentes na teoria do mínimo existencial. Trata-se, portanto, de direito subjetivo público à saúde.

\footnotetext{
35 Artigo 196 da Constituição Federal de 1.988

${ }^{36}$ Artigo 34, inciso VII, alínea "e" da Constituição Federal de 1.988

37 Art. 23 da Constituição Federal de 1.988. É competência comum da União, dos Estados, do Distrito Federal e dos Municípios: I - zelar pela guarda da Constituição, das leis e das instituições democráticas e conservar o patrimônio público;
} 
É de tal relevância social e de interesse público que a Constituição determinou ser competência de o Parquet zelar pelo efetivo respeito dos Poderes Públicos e dos serviços de relevância pública aos direitos assegurados nesta Constituição, promovendo as medidas necessárias a sua garantia; em seu art. 129, inciso II.

Dentre as medidas necessárias, pode-se falar do ajuizamento de ação civil pública, das ações de inconstitucionalidade (tanto a ação direta de inconstitucionalidade como a ação direta de inconstitucionalidade por omissão), bem como do mandado de injunção. As referidas ações visam provocar o Poder Judiciário no combate às inconstitucionalidades perpetradas pelos entes federado, para assegurar a efetiva disponibilidade dos direitos fundamentais de segunda dimensão.

Nesse sentido, colacionam-se os novéis julgados do Supremo Tribunal Federal sobre o tema:

EMENTA DIREITO CONSTITUCIONAL E CIVIL. SAÚDE. TRATAMENTO MÉDICO. ÚLCERA DE PERNA. SESSÕES DE OXIGENOTERAPIA HIPERBÁRICA. PLANO DE SAÚDE - CUSTEIO. ANÁLISE DA MOLDURA FÁTICA DELINEADA NO ACÓRDÃO REGIONAL. SOLIDARIEDADE DOS ENTES FEDERATIVOS. PRECEDENTES. (...). A jurisprudência desta corte firmou-se no sentido de que a saúde é direito de todos. É dever do estado de prestar assistência à saúde, conforme art. 196 da constituição federal, podendo o requerente pleitear de qualquer um dos entes federativos - união, estados, distrito federal ou municípios. Precedentes. Agravo regimental conhecido e não provido. (grifou-se). ${ }^{38}$

\footnotetext{
${ }^{38}$ AI 842740 AGR, RELATOR(A): MIN. ROSA WEBER, PRIMEIRA TURMA, JULGADO EM 09/04/2014, ACÓRDÃO ELETRÔNICO DJE-082 DIVULG 30-04-2014 PUBLIC 02-052014.
} 
E M E N T A: RECURSO EXTRAORDINÁRIO COM AGRAVO (LEI No 12.322/2010) - Custeio, pelo estado, de serviços hospitalares prestados por instituições privadas em benefício de pacientes do sus atendidos pelo samu nos casos de urgência e de inexistência de leitos na rede pública dever estatal de assistência à saúde e de proteção à vida resultante de norma constitucional - obrigação jurídico-constitucional que se impõe aos estados - configuração, no caso, de típica hipótese de omissão inconstitucional imputável ao estado - desrespeito à constituição provocado por inércia estatal (RTJ 183/818-819) - comportamento que transgride a autoridade da lei fundamental da república (RTJ 185/794-796) a questão da reserva do possível: reconhecimento de sua inaplicabilidade, sempre que a invocação dessa cláusula puder comprometer o núcleo básico que qualifica o mínimo existencial (RTJ 200/191-197) - o papel do poder judiciário na implementação de políticas públicas instituídas pela constituição e não efetivadas pelo poder público - a fórmula da reserva do possível na perspectiva da teoria dos custos dos direitos: impossibilidade de sua invocação para legitimar o injusto inadimplemento de deveres estatais de prestação constitucionalmente impostos ao poder público - a teoria da "restrição das restrições" (ou da "limitação das limitações") - caráter cogente e vinculante das normas constitucionais, inclusive daquelas de conteúdo programático, que veiculam diretrizes de políticas públicas, especialmente na área da saúde (CF, arts. 6", 196 e 197) - a questão das "escolhas trágicas" - a colmatação de omissões inconstitucionais como necessidade institucional fundada em comportamento afirmativo dos juízes e tribunais e de que resulta uma positiva criação jurisprudencial do direito - controle jurisdicional de legitimidade da omissão do poder público: atividade de fiscalização judicial que se justifica pela necessidade de observância de certos parâmetros constitucionais (proibição de retrocesso social, proteção ao mínimo existencial, vedação da proteção insuficiente e proibição de excesso) doutrina - precedentes do supremo tribunal federal em tema de 
implementação de políticas públicas delineadas na constituição da república (RTJ 174/687 - RTJ 175/1212-1213 - RTJ 199/1219-1220) - existência, no caso em exame, de relevante interesse social. 2. Ação civil pública: instrumento processual adequado à proteção jurisdicional de direitos revestidos de metaindividualidade - legitimação ativa do ministério público (CF, art. 129, III) - a função institucional do ministério público como "defensor do povo" (CF, art. 129, II) - doutrina - precedentes. 3. Responsabilidade solidária das pessoas políticas que integram o estado federal brasileiro, no contexto do sistema único de saúde (SUS) competência comum dos entes federados (união, estados-membros, distrito federal e municípios) em tema de proteção e assistência à saúde pública e/ou individual (CF, art. 23, II). Determinação constitucional que, ao instituir o dever estatal de desenvolver ações e de prestar serviços de saúde, torna as pessoas políticas responsáveis solidárias pela concretização de tais obrigações jurídicas, o que lhes confere legitimação passiva "ad causam" nas demandas motivadas por recusa de atendimento no âmbito do SUS - consequente possibilidade de ajuizamento da ação contra um, alguns ou todos os entes estatais - precedentes - recurso de agravo improvido. (grifou-se) ${ }^{39}$.

Diante da característica de direito fundamental indispensável à sociedade, os Tribunais brasileiros possuem entendimentos relevantes acerca do direito à saúde. Além dos já explicitados, a Corte Constitucional admite a possibilidade de, na falta de leitos ou outras formas de internação na rede de saúde pública, o Estado arcar com a internação do paciente nas redes privadas.

Situação que merece destaque, todavia, é a tratada em decisões dos Tribunais que permitem, na falta de remédios ou na prescrição de determinado medicamento não disponibilizado pela rede pública, que deve o

\footnotetext{
39 ARE 727864 AGR, RELATOR(A): MIN. CELSO DE MELLO, SEGUNDA TURMA, JULGADO EM 04/11/2014, ACÓRDÃO ELETRÔNICO DJE-223 DIVULG 12-11-2014 PUBLIC 13-11-2014
} 
Estado, do mesmo modo, fornecê-lo às suas custas aos pacientes hipossuficientes que fazem tratamentos específicos. O tema é tratado na Repercussão Geral do RE 657718, tema de nº 500. Percebe-se que a Suprema Corte tende a deferir os pedidos dos pacientes, conforme se verifica em diversas decisões. A controvérsia foi suscitada em novembro de 2011; contudo, o caso ainda está pendente de julgamento.

Abaixo, colaciona-se a ementa do caso de um julgado que exemplifica como têm se posicionado os Tribunais:

SAÚDE - MEDICAMENTO - FALTA DE REGISTRO NA AGÊNCIA NACIONAL DE VIGILÂNCIA SANITÁRIA - AUSÊNCIA DO DIREITO ASSENTADA NA ORIGEM - RECURSO EXTRAORDINÁRIO - REPERCUSSÃO GERAL CONFIGURAÇÃO. Possui repercussão geral a controvérsia acerca da obrigatoriedade, ou não, de o estado, ante o direito à saúde, constitucionalmente garantido, fornecer medicamento não registrado na agência nacional de vigilância sanitária - ANVISA. (grifou-se) ${ }^{40}$.

EMENTA: AGRAVO REGIMENTAL NA SUSPENSÃO DE TUTELA ANTECIPADA. DIREITOS FUNDAMENTAIS SOCIAIS. DIREITO À SAÚDE. SISTEMA ÚNICO DE SAÚDE. FORNECIMENTO DE MEDICAMENTO INDISPENSÁVEL PARA O TRATAMENTO DE DOENÇA GENÉTICA RARA. MEDICAÇÃO SEM REGISTRO NA ANVISA. NÃO COMPROVAÇÃO DO RISCO DE GRAVE LESÃO À ORDEM E À ECONOMIA PÚBLICAS. POSSIBILIDADE DE OCORRÊNCIA DE DANO INVERSO. AGRAVO REGIMENTAL A QUE SE NEGA PROVIMENTO. I - a decisão agravada não ultrapassou os limites normativos para a suspensão de segurança, isto é, circunscreveu-se à análise dos pressupostos do pedido, quais sejam, juízo mínimo de delibação sobre a

\footnotetext{
40 RE 657718 RG, RELATOR(A): MIN. MARCO AURÉLIO, JULGADO EM 17/11/2011, ACÓRDÃO ELETRÔNICO DJE-051 DIVULG 09-03-2012 PUBLIC 12-03-2012 REPUBLICAÇÃO: DJE-092 DIVULG 10-05-2012 PUBLIC 11-05-2012
} 
natureza constitucional da matéria de fundo e existência de grave lesão à ordem, à segurança, à saúde, à segurança e à economia públicas, nos termos do disposto no art. 297 do ristf. II - constatação de periculum in mora inverso, ante a imprescindibilidade do fornecimento de medicamento para melhora da saúde e manutenção da vida do paciente. III - agravo regimental a que se nega provimento. (grifou-se) ${ }^{41}$.

Ao analisar o princípio da isonomia aplicado aos casos de tutela ao direito à saúde, interessante apresentar o caso de repercussão geral do RE 581.488. O recente julgado trata da situação de impossibilidade de haver qualquer tratamento diferenciado a pacientes internados no SUS (Sistema Único de Saúde), sendo, pois, incompatível com o acesso equânime e universal às ações e serviços para promoção, proteção e recuperação da saúde, violando, ainda, os princípios da igualdade e da dignidade da pessoa humana:

EMENTA DIREITO CONSTITUCIONAL E ADMINISTRATIVO. AÇÃO CIVIL PÚBLICA. ACESSO DE PACIENTE À INTERNAÇÃO PELO SISTEMA ÚNICO DE SAÚDE (SUS) COM A POSSIBILIDADE DE MELHORIA DO TIPO DE ACOMODAÇÃO RECEBIDA E DE ATENDIMENTO POR MÉDICO DE SUA CONFIANÇA MEDIANTE O PAGAMENTO DA DIFERENÇA ENTRE OS VALORES CORRESPONDENTES. INCONSTITUCIONALIDADE. VALIDADE DE PORTARIA QUE EXIGE TRIAGEM PRÉVIA PARA A INTERNAÇÃo PELO SISTEMA PÚBLICO DE SAÚDE. ALCANCE DA NORMA DO ART. 196 DA CONSTITUIÇÃO FEDERAL. Recurso extraordinário a que se nega provimento. 1 . É constitucional a regra que veda, no âmbito do sistema único de saúde, a internação em acomodações superiores, bem como o atendimento diferenciado por médico do próprio sistema único de saúde (SUS) ou por conveniado,

\footnotetext{
${ }^{41}$ STA 761 AGR, RELATOR(A): MIN. RICARDO LEWANDOWSKI (PRESIDENTE), TRIBUNAL PLENO, JULGADO EM 07/05/2015, PROCESSO ELETRÔNICO DJE-101 DIVULG 28-05-2015 PUBLIC 29-05-2015
} 
mediante o pagamento da diferença dos valores correspondentes. 2. $O$ procedimento da "diferença de classes", tal qual o atendimento médico diferenciado, quando praticados no âmbito da rede pública, não apenas subverte a lógica que rege o sistema de seguridade social brasileiro, como também afronta o acesso equânime e universal às ações e serviços para promoção, proteção e recuperação da saúde, violando, ainda, os princípios da igualdade e da dignidade da pessoa humana. Inteligência dos arts. $1^{\circ}$, inciso III; $5^{\circ}$, inciso I; e 196 da Constituição Federal. 3. Não fere o direito à saúde, tampouco a autonomia profissional do médico, o normativo que veda, no âmbito do SUS, a assistência diferenciada mediante pagamento ou que impõe a necessidade de triagem dos pacientes em postos de saúde previamente à internação. 4. Recurso extraordinário a que se nega provimento. (grifou-se) $)^{42}$.

\footnotetext{
${ }^{42}$ RE 581.488, RELATOR(A): MIN. DIAS TOFFOLI, TRIBUNAL PLENO, JULGADO EM 03/12/2015, ACÓRDÃO ELETRÔNICO REPERCUSSÃO GERAL - MÉRITO DJE-065 DIVULG 07-04-2016 PUBLIC 08-04-2016
} 


\section{O DIREITO SOCIAL À EDUCAÇÃO}

A educação, direito de todos e dever do Estado e da família, será promovida e incentivada com a colaboração da sociedade, visando ao pleno desenvolvimento da pessoa, seu preparo para o exercício da cidadania e sua qualificação para o trabalho ${ }^{43}$.

A criança e o adolescente têm direito à educação, visando ao pleno desenvolvimento de sua pessoa, preparo para o exercício da cidadania e qualificação para o trabalho, assegurando-se-lhes: $(\ldots)^{44}$

Assim como o direito à saúde, o direito à educação também é direito fundamental de segunda dimensão e é espécie do rol dos direitos sociais. Da mesma forma, trata de direito subjetivo público, pelo qual os cidadãos e, principalmente, as crianças, pela peculiaridade em que se encontram, têm direito à educação obrigatória e gratuita. Nesse sentido, estabelece o art. 208, $\S 1^{\mathrm{o}}$ da Constituição: $O$ acesso ao ensino obrigatório e gratuito é direito público subjetivo.

Percebe-se que não só a Constituição Federal garante este dever, mas também a legislação infraconstitucional, e, de forma primordial, o Estatuto da Criança e do Adolescente, pois é principalmente na fase da infância, adolescência e juventude que a educação de fato transforma a vida dos cidadãos.

Dessa maneira, pela importância que existe no dever de o Estado oferecer educação a todos, deve ser ofertada desde a infância, passando pela adolescência e chegando até os jovens para que essa população em formação tenha condições dignas de manter seu futuro.

\footnotetext{
${ }^{43}$ Artigo 205 da Constituição Federal de 1.998.

${ }^{44}$ Artigo 53 do ECA
} 
Importante projeto de política pública para beneficiar famílias que estavam em situação de miserabilidade e de pobreza foi introduzido no ano de 2.004. Chamado de "Bolsa Família", o projeto conta com assistência pecuniária a grupos familiares que, atualmente, possuem renda menor do que $\mathrm{R} \$ 85,00$ por pessoa.

O auxílio fornecido pelo Estado corresponde a um valor variável entre $\mathrm{R} \$ 39,00$ por pessoa ou $\mathrm{R} \$ 85,00$ mensais por família, podendo, quando se tratar de família composta por gestante, lactante ou crianças e adolescentes, chegar ao patamar de R \$ 195,00 mensais. O valor máximo que uma família pode auferir pelo projeto corresponde a $\mathrm{R} \$ 372,00$ mensais, quando em situação de extrema pobreza ${ }^{45}$.

De fato, o projeto mostra um avanço pelo Poder Executivo em tentar garantir a vida dessas pessoas mais viabilidade de seus sustentos, diminuir os índices de miserabilidade do país, além de propor às novas gerações um contexto social econômico melhor. O programa é imprescindível, na medida em que viabiliza às famílias brasileiras que saiam da situação de miserabilidade e possam investir na educação de seus familiares, já que é imprescindível que os jovens estejam estudando regularmente. Todavia, corresponde, no melhor das hipóteses, a quase 1/3 do salário mínimo atual, o que reflete um valor módico, quando comparado com o custo de vida brasileiro.

Em relação ao direito à educação, um dos requisitos essenciais para fazer jus ao benefício é que se mantenha a frequência mínima de $85 \%$ na escola, para crianças e adolescentes de 6 a 15 anos, e de $75 \%$ para adolescentes de 16 a 17 anos. Entretanto, mesmo com a inserção de uma política pública essencial que promove benefícios pecuniários, deve o Estado promover outras para que as famílias brasileiras que compõem as classes

\footnotetext{
45 Programa "Bolsa Família" disponibilizado em http://www.caixa.gov.br/programas-sociais/bolsafamilia/Paginas/default.aspx
} 
mais baixas consigam manter seu sustento de forma digna. Ademais, há famílias que não participam do benefício, por não cumprirem os requisitos básicos, e ainda assim não tem acesso à educação de qualidade, havendo ainda brasileiros ignorantes, que fomentam o trabalho nos setores que privilegiam a mão-de-obra braçal, o trabalho análogo ao de escravo, bem como o trabalho infantil.

Diversos fatores políticos propiciam esse cenário e devem ser combatidos, dentre eles a falta de vontade do Poder Público em criar escolas no interior do país, a existência de escolas públicas de péssima qualidade ou a quilômetros de distância dos grupos familiares, os baixos salários dos professores da rede pública, que constantemente fazem greve, a necessidade das famílias de baixa renda em colocar seus filhos para trabalhar, entre outros motivos. Enfim, são inúmeras e tristes razões.

A legislação, contudo, tenta minimizar essa lamentável realidade. Não tendo sido ofertado o ensino no tempo devido, a Constituição e o ECA, para minimizar os efeitos de uma educação tardia, determinam que deva ser oferecido o direito à educação àqueles que, infelizmente, não gozaram das mesmas oportunidades, a qualquer tempo. Por isso, afirmam que:

O dever do Estado com a educação será efetivado mediante a garantia de: I educação básica obrigatória e gratuita dos 4 (quatro) aos 17 (dezessete) anos de idade, assegurada inclusive sua oferta gratuita para todos os que a ela não tiveram acesso na idade própria; ${ }^{46}$

É dever do Estado assegurar à criança e ao adolescente: I - ensino fundamental, obrigatório e gratuito, inclusive para os que a ele não tiveram acesso na idade própria; ${ }^{47}$

\footnotetext{
${ }^{46}$ Artigo 208 da Constituição Federal de 1.988.

${ }^{47}$ Artigo 54 do Estatuto da Criança e do Adolescente
} 
Posto isso, percebe-se que o ensino básico é obrigatório e gratuito, motivo pelo qual deve estar inserido nos programas de governo. Assim como o direito à saúde, caso haja violação do Estado em cumprir este dever, situação que se enquadrará em plena omissão inconstitucional, por se tratar de direito subjetivo público, o cidadão tem a possibilidade de coagir o Estado, por meio do Poder Judiciário, a fazer valer seu direito.

Na verdade, no caso das crianças e adolescentes, a legislação vai além. Não se trata, apenas, de uma possibilidade, mas sim de dever de coibir o Estado. Isso porque, o Estatuto estabelece em seu art. 55 que: os pais ou responsável têm a obrigação de matricular seus filhos ou pupilos na rede regular de ensino. Assim, podem os pais ou responsáveis do menor de idade ser punidos pela falta de matricula da criança em escola. Ressalta-se, pois, por este comando, a valorização e a relevância que o ordenamento jurídico, em resposta aos anseios sociais, confere ao direito à educação no tempo devido.

A propósito, colaciona-se precedente do Tribunal de Justiça do Estado do Rio de Janeiro que, por falta de regular matricula do menor de idade, determinou a perda da guarda exercida pela genitora:

AGRAVO DE INSTRUMENTO. GUARDA PROVISÓRIA. DIREITO À EDUCAÇÃO. OBRIGAÇÃO LEGAL DOS PAIS E RESPONSÁVEIS DE MATRICULAR OS FILHOS OU PUPILOS NA REDE REGULAR DE ENSINO. ABANDONO INTELECTUAL. MELHOR INTERESSE DO MENOR. A Constituição da Republica, no seu art. 227, e o ECA, no seu art. 19, asseguram o direito da criança ao convívio familiar. Compete a ambos os pais o exercício do poder familiar, que consiste no sustento, guarda e educação, em aspecto amplo, dos menores, a fim de protegê-los e proporcioná-los o melhor desenvolvimento possível, tanto no campo afetivo, como social e familiar, visto que isso é fundamental elemento no desenvolvimento da personalidade da criança. A guarda será atribuída ao 
cônjuge que possuir melhores condições para exercê-la. Tal dispositivo deve ser interpretado considerando não apenas as condições, mas se atendem ao melhor interesse do menor, preceito inafastável por força do art. 227 da Constituição da República. Enquanto esteve sob a guarda da genitora, a menor não frequentava a escola. Estatuto da Criança e do Adolescente dispõe expressamente em seus artigos 55 e 129, V sobre a obrigação dos pais de matricular os filhos na rede regular de ensino e acompanhar sua frequência e aproveitamento escolar. $O$ argumento da genitora não lhe socorre. Ainda que a genitora não tivesse condições de manter sua filha em instituição particular de ensino, tem o dever legal de matriculá-la em escola da rede pública, sob pena de incorrer na prática de abandono intelectual (art. 246 do Código Penal). A criança só possui nove anos, sendo imprescindível que frequente a escola. Genitor providenciou a matrícula de sua filha em instituição de ensino particular, observando o melhor interesse da menor. Não há qualquer risco para menor na sua permanência sob a guarda provisória do pai. Considerando que a situação permanece inalterada, sem qualquer fato novo, mantenho a decisão como determinada em primeiro grau. Aplicação do verbete n. 58 da Súmula do TJRJ. Desprovimento do recurso. (grifou-se) ${ }^{48}$.

Os Tribunais superiores têm entendimento consolidado no sentido de que a alegação, por parte do ente federado, de que não há vaga em creche ou escola não basta para que se descumpra o direito social à educação. Nessa perspectiva, colaciona-se importante julgado sobre o tema, discutido no âmbito do Supremo Tribunal Federal, que admite, inclusive, o ativismo jurídico, posto que, por se tratar de direito incluído pelo mínimo existencial, não aceita a aplicação de qualquer tese sobre a reserva do possível:

E M E N T A: CRIANÇA DE ATÉ CINCO ANOS DE IDADE ATENDIMENTO EM CRECHE E EM PRÉ-ESCOLA - SENTENÇA

48 0037722-83.2011.8.19.0000 - AGRAVO DE INSTRUMENTO. Ementa. TERESA DE ANDRADE CASTRO NEVES - SEXTA CÂMARA CÍVEL. Data de julgamento: 08/02/2012. 
QUE OBRIGA O MUNICÍPIO DE SÃO PAULO A MATRICULAR CRIANÇAS EM UNIDADES DE ENSINO INFANTIL PRÓXIMAS DE SUA RESIDÊNCIA OU DO ENDEREÇO DE TRABALHO DE SEUS RESPONSÁVEIS LEGAIS, SOB PENA DE MULTA DIÁRIA POR CRIANÇA NÃO ATENDIDA - LEGITIMIDADE JURÍDICA DA UTILIZAÇÃO DAS “ASTREINTES” CONTRA O PODER PÚBLICO DOUTRINA - JURISPRUDÊNCIA - OBRIGAÇÃO ESTATAL DE RESPEITAR OS DIREITOS DAS CRIANÇAS - EDUCAÇÃO INFANTIL - DIREITO ASSEGURADO PELO PRÓPRIO TEXTO CONSTITUCIONAL (CF, ART. 208, IV, NA REDAÇÃO DADA PELA EC $\mathrm{N}^{\circ}$ 53/2006) - COMPREENSÃO GLOBAL DO DIREITO CONSTITUCIONAL À EDUCAÇÃO - DEVER JURÍDICO CUJA EXECUÇÃO SE IMPÕE AO PODER PÚBLICO, NOTADAMENTE AO MUNICÍPIO (CF, ART. 211, $§ 2^{\circ}$ ) - LEGITIMIDADE CONSTITUCIONAL DA INTERVENÇÃO DO PODER JUDICIÁRIO EM CASO DE OMISSÃO ESTATAL NA IMPLEMENTAÇÃO DE POLÍTICAS PÚBLICAS PREVISTAS NA CONSTITUIÇÃO INOCORRÊNCIA DE TRANSGRESSÃO AO POSTULADO DA SEPARAÇÃO DE PODERES - PROTEÇÃO JUDICIAL DE DIREITOS SOCIAIS, ESCASSEZ DE RECURSOS E A QUESTÃO DAS "ESCOLHAS TRÁGICAS" - RESERVA DO POSSÍVEL, MÍNIMO EXISTENCIAL, DIGNIDADE DA PESSOA HUMANA E VEDAÇÃO DO RETROCESSO SOCIAL - PRETENDIDA EXONERAÇÃO DO ENCARGO CONSTITUCIONAL POR EFEITO DE SUPERVENIÊNCIA DE NOVA REALIDADE FÁTICA - QUESTÃO QUE SEQUER FOI SUSCITADA NAS RAZÕES DE RECURSO EXTRAORDINÁRIO PRINCÍPIO "JURA NOVIT CURIA" - INVOCAÇÃO EM SEDE DE APELO EXTREMO - IMPOSSIBILIDADE - RECURSO DE AGRAVO IMPROVIDO. POLÍTICAS PÚBLICAS, OMISSÃO ESTATAL INJUSTIFICÁVEL E INTERVENÇÃO CONCRETIZADORA DO PODER JUDICIÁRIO EM TEMA DE EDUCAÇÃO INFANTIL: 
POSSIBILIDADE CONSTITUCIONAL. - A educação infantil representa prerrogativa constitucional indisponível, que, deferida às crianças, a estas assegura, para efeito de seu desenvolvimento integral, e como primeira etapa do processo de educação básica, o atendimento em creche e o acesso à préescola (CF, art. 208, IV). - Essa prerrogativa jurídica, em consequiência, impõe, ao Estado, por efeito da alta significação social de que se reveste a educação infantil, a obrigação constitucional de criar condições objetivas que possibilitem, de maneira concreta, em favor das "crianças até 5 (cinco) anos de idade" (CF, art. 208, IV), o efetivo acesso e atendimento em creches e unidades de pré-escola, sob pena de configurar-se inaceitável omissão governamental, apta a frustrar, injustamente, por inércia, o integral adimplemento, pelo Poder Público, de prestação estatal que lhe impôs o próprio texto da Constituição Federal. - A educação infantil, por qualificarse como direito fundamental de toda criança, não se expõe, em seu processo de concretização, a avaliações meramente discricionárias da Administração Pública nem se subordina a razões de puro pragmatismo governamental. - Os Municípios - que atuarão, prioritariamente, no ensino fundamental e na educação infantil $\left(\mathrm{CF}\right.$, art. $\left.211, \S 2^{\circ}\right)$ - não poderão demitir-se do mandato constitucional, juridicamente vinculante, que lhes foi outorgado pelo art. 208, IV, da Lei Fundamental da República, e que representa fator de limitação da discricionariedade político-administrativa dos entes municipais, cujas opções, tratando-se do atendimento das crianças em creche (CF, art. 208, IV), não podem ser exercidas de modo a comprometer, com apoio em juízo de simples conveniência ou de mera oportunidade, a eficácia desse direito básico de índole social. - Embora inquestionável que resida, primariamente, nos Poderes Legislativo e Executivo, a prerrogativa de formular e executar políticas públicas, revela-se possível, no entanto, ao Poder Judiciário, ainda que em bases excepcionais, determinar, especialmente nas hipóteses de políticas públicas definidas pela própria Constituição, sejam estas implementadas, sempre que os órgãos estatais competentes, por descumprirem os encargos político- -jurídicos que sobre eles incidem em 
caráter impositivo, vierem a comprometer, com a sua omissão, a eficácia e a integridade de direitos sociais e culturais impregnados de estatura constitucional. DESCUMPRIMENTO DE POLÍTICAS PÚBLICAS DEFINIDAS EM SEDE CONSTITUCIONAL: HIPÓTESE LEGITIMADORA DE INTERVENÇÃO JURISDICIONAL. - O Poder Público - quando se abstém de cumprir, total ou parcialmente, o dever de implementar políticas públicas definidas no próprio texto constitucional transgride, com esse comportamento negativo, a própria integridade da Lei Fundamental, estimulando, no âmbito do Estado, o preocupante fenômeno da erosão da consciência constitucional. Precedentes: ADI 1.484/DF, Rel. Min. CELSO DE MELLO, v.g.. - A inércia estatal em adimplir as imposições constitucionais traduz inaceitável gesto de desprezo pela autoridade da Constituição e configura, por isso mesmo, comportamento que deve ser evitado. É que nada se revela mais nocivo, perigoso e ilegítimo do que elaborar uma Constituição, sem a vontade de fazê-la cumprir integralmente, ou, então, de apenas executá-la com o propósito subalterno de torná-la aplicável somente nos pontos que se mostrarem ajustados à conveniência e aos desígnios dos governantes, em detrimento dos interesses maiores dos cidadãos. - A intervenção do Poder Judiciário, em tema de implementação de políticas governamentais previstas e determinadas no texto constitucional, notadamente na área da educação infantil (RTJ 199/1219-1220), objetiva neutralizar os efeitos lesivos e perversos, que, provocados pela omissão estatal, nada mais traduzem senão inaceitável insulto a direitos básicos que a própria Constituição da República assegura à generalidade das pessoas. Precedentes. A CONTROVÉRSIA PERTINENTE À “RESERVA DO POSSÍVEL" E A INTANGIBILIDADE DO MÍNIMO EXISTENCIAL: A QUESTÃo dAS “ESCOLHAS TRÁGICAS”. - A destinação de recursos públicos, sempre tão dramaticamente escassos, faz instaurar situações de conflito, quer com a execução de políticas públicas definidas no texto constitucional, quer, também, com a própria implementação de direitos sociais assegurados pela Constituição da República, daí resultando contextos 
de antagonismo que impõem, ao Estado, o encargo de superá-los mediante opções por determinados valores, em detrimento de outros igualmente relevantes, compelindo, o Poder Público, em face dessa relação dilemática, causada pela insuficiência de disponibilidade financeira e orçamentária, a proceder a verdadeiras "escolhas trágicas", em decisão governamental cujo parâmetro, fundado na dignidade da pessoa humana, deverá ter em perspectiva a intangibilidade do mínimo existencial, em ordem a conferir real efetividade às normas programáticas positivadas na própria Lei Fundamental. Magistério da doutrina. - A cláusula da reserva do possível - que não pode ser invocada, pelo Poder Público, com o propósito de fraudar, de frustrar e de inviabilizar a implementação de políticas públicas definidas na própria Constituição - encontra insuperável limitação na garantia constitucional do mínimo existencial, que representa, no contexto de nosso ordenamento positivo, emanação direta do postulado da essencial dignidade da pessoa humana. Doutrina. Precedentes. - A noção de "mínimo existencial”, que resulta, por implicitude, de determinados preceitos constitucionais $(\mathrm{CF}$, art. $1^{\circ}$, III, e art. $3^{\circ}$, III), compreende um complexo de prerrogativas cuja concretização revela-se capaz de garantir condições adequadas de existência digna, em ordem a assegurar, à pessoa, acesso efetivo ao direito geral de liberdade e, também, a prestações positivas originárias do Estado, viabilizadoras da plena fruição de direitos sociais básicos, tais como o direito à educação, o direito à proteção integral da criança e do adolescente, o direito à saúde, o direito à assistência social, o direito à moradia, o direito à alimentação e o direito à segurança. Declaração Universal dos Direitos da Pessoa Humana, de 1948 (Artigo XXV). A PROIBIÇÃo DO RETROCESSO SOCIAL COMO OBSTÁCULO CONSTITUCIONAL À FRUSTRAÇÃO E AO INADIMPLEMENTO, PELO PODER PÚBLICO, DE DIREITOS PRESTACIONAIS. - O princípio da proibição do retrocesso impede, em tema de direitos fundamentais de caráter social, que sejam desconstituídas as conquistas já alcançadas pelo cidadão ou pela formação social em que ele vive. - A cláusula que veda o retrocesso em 
matéria de direitos a prestações positivas do Estado (como o direito à educação, o direito à saúde ou o direito à segurança pública, v.g.) traduz, no processo de efetivação desses direitos fundamentais individuais ou coletivos, obstáculo a que os níveis de concretização de tais prerrogativas, uma vez atingidos, venham a ser ulteriormente reduzidos ou suprimidos pelo Estado. Doutrina. Em consequência desse princípio, o Estado, após haver reconhecido os direitos prestacionais, assume o dever não só de torná-los efetivos, mas, também, se obriga, sob pena de transgressão ao texto constitucional, a preservá-los, abstendo-se de frustrar - mediante supressão total ou parcial - os direitos sociais já concretizados. LEGITIMIDADE JURÍDICA DA IMPOSIÇÃO, AO PODER PÚBLICO, DAS "ASTREINTES". - Inexiste obstáculo jurídico-processual à utilização, contra entidades de direito público, da multa cominatória prevista no $§ 5^{\circ}$ do art. 461 do CPC. A "astreinte" - que se reveste de função coercitiva - tem por finalidade específica compelir, legitimamente, o devedor, mesmo que se cuide do Poder Público, a cumprir o preceito, tal como definido no ato sentencial. Doutrina. Jurisprudência. (grifou-se) ${ }^{49}$.

\footnotetext{
49 ARE 639337 AgR, Relator(a): Min. CELSO DE MELLO, Segunda Turma, julgado em 23/08/2011, DJe-177 DIVULG 14-09-2011 PUBLIC 15-09-2011 EMENT VOL-02587-01 PP00125
} 


\section{A IMPOSSIBILIDADE DE APLICAÇÃO DA TEORIA DA RESERVA DO POSSÍVEL DIANTE DA DOUTRINA DO MÍNIMO EXISTENCIAL E O CONTEXTO SÓCIO- ECONÔMICO BRASILEIRO}

\section{VI.I ORIGEM E ANÁLISE DA TEORIA DA RESERVA DO POSSÍVEL}

A teoria da reserva do possível, utilizada atualmente pelo Poder Executivo no bojo de ações judiciais que buscam o provimento jurisdicional para o acesso à educação pública, tratamento médico-hospitalar e medicamentoso, com o objetivo de não adimplir as obrigações a ele impostas pela Constituição Federal, foi desenvolvida pelo Tribunal Constitucional Federal da Alemanha, na década de 70, no leading case Numeros Clausus $\mathrm{I}^{50}$.

O caso concreto trata do ingresso de estudantes alemães nos cursos de ciências naturais em universidades públicas, diante da previsão do direito à liberdade de escolha de profissão, em sua Constituição de 1.949, atualmente vigente, segundo dispõe o artigo $12, \mathrm{n}^{\mathrm{o}} 1$ :

Todos os alemães têm o direito de eleger livremente a sua profissão, o lugar de trabalho e o de aprendizagem $(. . .)^{51}$.

Acontece que, no período compreendido entre os anos 50 a 70, o número de alunos interessados nesses cursos aumentou de uma maneira exorbitante, sem que houvesse a expansão de universidades pelo Poder Público. O contexto histórico de pós-guerra inviabilizou o governo de promover investimentos na área e, a partir de 1.968 , houve a criação de leis

\footnotetext{
${ }^{50}$ BVerfGE 33, 303, de 1973. Caso alemão paradigma Numerus Clausus I. Tradução livre. http://www.servat.unibe.ch/dfr/bv033303.html

${ }^{51}$ Constituição da República Federal da Alemanha, disponibilizada em

http://www.brasil.diplo.de/contentblob/3160404/Daten/1330556/Gundgesetz_pt.pdf
} 
que estabeleciam restrições à admissão dos alunos, principalmente nos cursos superiores de medicina.

Apesar da situação, o Governo Federal se propôs a desenvolver um plano educacional, fomentado por um orçamento com destinação específica a esse plano, a fim de viabilizar a entrada dos futuros calouros nos cursos de medicina oferecidos pelo Estado. Mesmo assim, a reforma das universidades não conseguiu viabilizar a demanda e, com isso, não pôde evitar as leis que impunham contenções na admissão dos estudantes.

Ao se deparar com o caso, a Corte Constitucional Alemã entendeu que, apesar do direito à educação e à livre escolha de profissão serem direitos fundamentais, não consegue o Estado suportá-lo de maneira indeterminada aos seus cidadãos e como pretendia o caso concreto. Assentou que as referidas leis são compatíveis com o texto constitucional, tendo em vista que não seria possível garantir o acesso universal e ilimitado ao ensino superior, ante a insuficiência de recursos orçamentários, que privilegiaria um número restrito de cursos relacionados às ciências naturais.

Assim, a tese de que o Estado deveria ser compelido a criar vagas nas universidades públicas de maneira satisfatória para atender a todos os candidatos foi, então, afastada. Decidiu, portanto, que o direito à liberdade de escolha da profissão, assegurado constitucionalmente, não significava, por outro modo, o amplo direito do cidadão de exigir vaga para o curso desejado. Isso porque não é razoável assegurar esta pretensão quando demande do Estado esforços excessivos para o fomento de determinado programa tão específico e que traga consequências para outras áreas de atuação governamental.

A partir disso, se pode tirar conclusões triviais.

Ora, o ponto nodal não está sobre o fato de não haver acesso à educação e ao ensino superior à população, por escassez total dos recursos 
financeiros. O direito à educação, direito fundamental de segunda dimensão, está sendo cumprido e disponibilizado pelo Governo alemão. O que não é sustentável é a ideia de que uma classe de indivíduos procure um provimento judicial que vise garantir a satisfação de cidadãos específicos, que buscam sua profissão em cursos determinados e que demandem altos investimentos.

Não é, pois, razoável que qualquer governo escolha transferir altos valores para cursos específicos, prejudicando o investimento em outras políticas públicas e sociais. Ademais, o investimento em cursos superiores de ciências naturais além dos que já existiam não se compatibilizava com o interesse público, interesse esse que fundamenta e norteia as escolhas orçamentárias e políticas de governo.

Quando estudiosos e aplicadores do direito buscam a inserção desta teoria no Brasil, devem estar atentos à realidade do país.

No Brasil, não obstante haja previsão constitucional do direito à educação, com o objetivo de alcançar toda a sociedade, não há uma disponibilidade efetiva de creches, escolas e professores na rede pública, e já não existe a garantia de ensino público superior à população. Ademais, apesar de ser assegurado o ensino fundamental, grande parte da sociedade está privada de ter um ensino de qualidade, em decorrência da má gestão administrativa e dos inúmeros escândalos de corrupção.

Nesse caso específico, inclusive, traz injustiças e consequências desumanas, já que confere ao Poder Público uma justificativa em não se esforçar para promover o impulso das políticas governamentais, que são aqui deficientes de forma abusiva, uma vez que os cidadãos brasileiros têm seus direitos violados constantemente, tanto na educação, como na saúde, na segurança pública, na busca por um trabalho digno, entre outros. 
Para se poder fazer uma comparação, apresentam-se alguns dados relevantes encontrados no site do $\mathrm{IBGE}^{52}$, referentes ao ano de 2016:
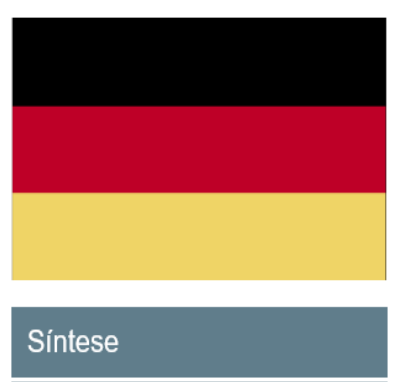

Dados Olimpicos

\section{Economia}

Indicadores sociais

Meio ambiente

População

Redes

\begin{tabular}{|c|c|}
\hline Entrada de turistas & 32.999 .000 turistas \\
\hline Gastos públicos com educação & $5,1 \%$ do PIB \\
\hline Gastos públicos com saúde & $11,3 \%$ do PIB \\
\hline Investimentos em pesquisa e desenvolvimento & $2,88 \%$ do PIB \\
\hline Mulheres de 15 anos ou mais de idade economicamente ativas & $52,65 \%$ \\
\hline PIB per capita & 41.686 US\$ \\
\hline População de 15 anos ou mais de idade economicamente ativa & $58,96 \%$ \\
\hline Total da exportação & 1.498.157,78 milhões de US\$ \\
\hline Total da importação & 1.214.955,67 milhões de US\$ \\
\hline Total do PIB & 3.363 .600 milhões de US\$ \\
\hline
\end{tabular}

52 IBGE, países - Alemanha, disponibilizado em

https://paises.ibge.gov.br/\#/pt/pais/alemanha/info/economia (acesso em 30/10/2017) 


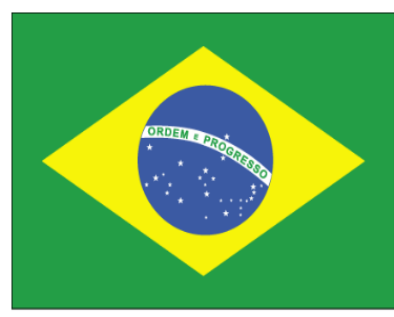

Economia

Entrada de turistas

Gastos públicos com educação

Gastos públicos com saúde

\section{Sintese}

\section{Dados Olímpicos}

Economia

Indicadores sociais

Meio ambiente

População

Redes

\begin{tabular}{lc}
\hline Investimentos em pesquisa e desenvolvimento & $1,15 \%$ do PIB \\
\hline Mulheres de 15 anos ou mais de idade economicamente ativas & $60,03 \%$ \\
\hline PIB per capita & 8.528 US\$ \\
\hline População de 15 anos ou mais de idade economicamente ativa & $69,7 \%$ \\
\hline Total da exportação & $225.098,41$ milhões de US\$ \\
\hline Total da importação & $229.060,06$ milhões de US\$ \\
\hline Total do PIB & 1.772 .591 milhões de US\$
\end{tabular}

O primeiro dado a ser analisado é o número do PIB per capita (produto interno bruto) de um país em comparação ao outro, pois é a partir desse montante que a tabela mostra a variação de investimento nos setores de cada Estado. Os investimentos no setor de educação de um país, por exemplo, são completamente discrepantes em relação ao outro. Isso também ocorre no setor da saúde e nos demais.

Na Alemanha, são investidos 5,1\% do PIB em gastos públicos com educação, que perfaz um valor de 17.154.360 milhões de dólares, enquanto que no Brasil, os investimentos em educação, apesar de serem equivalentes a 5,8\% do PIB, correspondem a um total de 10.281.028 milhões de dólares, ou seja, quase 7 milhões de dólares a menos.

Os gastos públicos com saúde, como dito, não são diferentes. Enquanto na Alemanha o investimento no setor é de 11,3\% do PIB, que totaliza 38.008.680 milhões de dólares, no Brasil o investimento gira em

\footnotetext{
${ }^{53}$ IBGE, países - Brasil, disponibilizado em https://paises.ibge.gov.br/\#/pt/pais/brasil/info/economia (acesso em 30/10/2017)
} 
torno de 17.194.132,7 milhões de dólares, ou seja, menos da metade do que é investido pelo governo estrangeiro.

Um outro dado relevante é o número de habitantes em cada país. Enquanto a Alemanha possui cerca de 80 milhões de habitantes, o Brasil possui quase 205 milhões, o que significa que quando a Alemanha investe 5,1\% do PIB em gastos públicos com educação e 11,3\% do PIB em gastos públicos com saúde, esses números abarcam com maior qualidade a população, que é demograficamente menor em comparação com o Estado brasileiro.

Como é possível, então, se ter a pretensão de aplicar uma teoria desenvolvida na Alemanha, em um caso concreto bastante peculiar, que aborda a inserção de estudantes em cursos específicos e que demandam altos investimento, no Brasil, país este que possui uma realidade completamente diferente e que pouco desenvolve nos setores sociais?

O que ocorre, na verdade, é uma discrepância entre os direitos viabilizados na República Federal da Alemanha e na República Federativa do Brasil, de modo que a aplicação da teoria da reserva do possível, em um contexto social e político diferente, não irá promover os mesmos resultados em ambos os países. Enquanto na Alemanha o Poder Executivo executa suas políticas públicas com excelência, no Brasil isso não ocorre e os mandamentos constitucionais não são, em sua grande maioria, cumpridos.

Nesse sentido, em uma palestra realizada na Escola de Direito do Rio de Janeiro da Fundação Getúlio Vargas, a ministra presidente da Suprema Corte, Cármen Lúcia, proferiu discurso com as seguintes palavras sobre a situação brasileira:

(...) O Brasil ainda vive uma situação de desigualdade social demasiadamente forte. E isso afeta profundamente a dignidade da pessoa humana. As diferenças sociais são tão estampadas que podem ser vistas, por exemplo, no céu de São Paulo: muitos se deslocam de helicóptero, enquanto outros vão ao trabalho a pé, muitas vezes 
andando quilômetros. Há ainda, em se tratando do Nordeste do Brasil, os que vão trabalhar montados no lombo de um jumento ou crianças que, para estudar, são transportadas na carroceria de algum caminhão. E o pior, quando chegam à escola, essas crianças não têm lugar para sentar, tal a precariedade da instituição. Enquanto isso, outras crianças são alfabetizadas em ótimos colégios que ensinam ainda duas ou três línguas estrangeiras. Ou seja, o Brasil vive uma desigualdade social tão grande, que se torna difícil sua mensuração. $(. . .)^{54}$

Portanto, não se vislumbra outra hipótese da presente teoria aplicada no Brasil que não tenha o viés de restringir os direitos fundamentais, na medida em que o Poder Público a utiliza para justificar a impossibilidade de investimento nos setores sociais garantidos na Constituição de 1.988.

\section{VI.II A DOUTRINA DO MÍNIMO EXISTENCIAL}

A doutrina do mínimo existencial, assim como a teoria da reserva do possível, também teve origem nos precedentes das Cortes Alemãs.

Aduz Ingo Sarlet ${ }^{55}$ que a doutrina tem origem com o Tribunal Federal Administrativo Alemão ao reconhecer ser direito subjetivo o fornecimento de auxílios por parte do Estado para os indivíduos que não possuem condições financeiras para o custeio de sua subsistência, tendo em vista o princípio da dignidade da pessoa humana, no caso BVerwGE 1, 159, julgado em 1.954 .

Após o pioneirismo da Corte Administrativa, o Tribunal Constitucional Federal Alemão, segundo o autor, reconheceu, no mesmo sentido, o direito fundamental à garantia das condições mínimas para a existência digna, definindo o Estado como um garantidor do núcleo essencial

\footnotetext{
${ }^{54}$ ROCHA, Cármen Lúcia Antunes. Palestra. Texto publicado na edição 252 da Revista de Direito Administrativo: http://www.editoraforum.com.br/ef/index.php/noticias/dignidade-da-pessoahumana-e-o-minimo-existencial/

${ }^{55}$ SARLET, Ingo. Dignidade (da pessoa) humana, mínimo existencial e justiça constitucional: algumas aproximações e alguns desafios. Revista do CEJUR/TJSC: Prestação Jurisdicional, v. 1, n⿳亠口冋 1, p. 29-44, dez. 2013
} 
de direitos que compõem o mínimo existencial, no caso sob judice BVerfGE 40, 121, duas décadas depois.

Dessa forma, o cidadão alemão que vive à margem da sociedade passou a ser titular de direitos e obrigações em face do Estado alemão, que deve prover as condições mínimas e necessárias à sua subsistência e existência.

Ricardo Lobo Torres, autor que iniciou o debate sobre o tema no Brasil, define o mínimo existencial como sendo o direito às condições mínimas de existência humana digna que não pode ser objeto da intervenção do Estado e que ainda exige prestações estatais positivas ${ }^{56}$. O jurista demonstra que esse núcleo essencial de direitos aparece desde a Constituição de 1.946 , como, por exemplo, em seu artigo $15, \S 1^{\circ}$, que determinava isentos de imposto de consumo os artigos que a lei classificar como o mínimo indispensável à habitação, vestuário, alimentação e tratamento médico das pessoas de restrita capacidade econômica, até a Constituição vigente, com a positivação dos direitos sociais.

Todavia, para o autor, não se trata tão somente de direitos que devem estar positivados constitucionalmente para que sejam observados. Os direitos que compõem o mínimo existencial estão presentes de forma implícita em princípios constitucionais, como os princípios da igualdade, do devido processo legal, da livre iniciativa, entre outros, abrangendo qualquer direito, ainda que originariamente não-fundamental (direito à saúde, à alimentação, etc.), considerado em sua dimensão essencial e inalienável ${ }^{57}$.

Não há dúvida de que essas obrigações prestacionais do Estado estão positivadas na Constituição Federal, em seu Capítulo II do Título II, e

\footnotetext{
${ }^{56}$ TORRES, Ricardo Lobo. O Mínimo Existencial e os Direitos Fundamentais, Revista de Direito Administrativo, RJ, (42) 1990. p. 69 a 75.

${ }^{57}$ TORRES, Ricardo Lobo. Op. cit. p. 73.
} 
abrangem todo o rol de direitos elencados dos artigos $6^{\circ}$ ao 11 , tratando dos direitos sociais em sua completude.

Nesse sentido, pode-se comparar o rol de direitos que compõem o mínimo existencial com os status civitatis de Jellinek, explicitados neste trabalho, já que ambos conferem aos cidadãos o direito de exigir do Estado e de suas instituições prestações positivas que possibilitam à sociedade o fornecimento de serviços intrínsecos à qualidade de vida digna.

Em mesma perspectiva, afirma Ricardo Lobo Torres que o mínimo existencial é direito protegido negativamente contra a intervenção do Estado, e isso se faz presente em decorrência do princípio da liberdade, direito fundamental de primeira dimensão, que estabelece que o Estado deve se abster de intervir nas liberdades dos indivíduos. São proteções negativas do mínimo existencial que podem ser exemplificadas pelas imunidades fiscais; e, ao mesmo tempo, garantido positivamente pelas prestações estatais, como ocorre com a assistência judiciária gratuita aos necessitados, garantia de ensino público primário e fornecimento de medicamentos àqueles que não têm a possibilidade de comprá-los. (...) é direito de status negativus e positivus ${ }^{58}$.

O conceito de mínimo existencial, contudo, apesar de não ser unânime entre os estudiosos do direito, de maneira geral se refere, como visto, a um núcleo básico de direitos fundamentais essenciais e intrínsecos ao indivíduo. Para Ingo Sarlet, (...) tem-se como certo que a garantia efetiva de uma existência digna abrange mais do que a garantia da mera sobrevivência física, situando-se, portanto, além do limite da pobreza absoluta ${ }^{59}$.

E o autor não para por aí, afirma que a ideia de mínimo existencial deve ir além para abarcar os direitos que possibilitam a inserção desse

\footnotetext{
${ }^{58}$ TORRES, Ricardo Lobo. Op. cit. p. 75

${ }^{59}$ SARLET, Ingo. Op. cit. p. 29-74.
} 
indivíduo marginalizado, havendo uma diferenciação entre o mínimo existencial fisiológico e o mínimo existencial sociocultural.

\section{A propósito:}

(...) verifica-se uma distinção importante no concernente ao conteúdo e alcance do próprio mínimo existencial, que tem sido desdobrado num assim designado mínimo fisiológico, que constitui, por compreender as condições materiais mínimas para uma vida condigna, no sentido da proteção contra necessidades de caráter existencial básico, o conteúdo essencial da garantia do mínimo existencial, e num assim designado mínimo existencial sociocultural, que, para além da proteção básica já referida, objetiva assegurar ao indivíduo um mínimo de inserção - em termos de tendencial igualdade - na vida social e cultural ${ }^{60}$.

Percebe-se, portanto, que o mínimo existencial é o núcleo básico de direitos fundamentais de segunda dimensão, consubstanciados na dignidade da pessoa humana, valor máximo da Constituição vigente, que geram prestações ao Estado e direitos subjetivos aos seus cidadãos, podendo, portanto, lhe exigir o cumprimento.

Ademais, pode-se encontrar a positivação do que se chama de mínimo existencial também no plano internacional, principalmente na Declaração Universal dos Direitos da Pessoa Humana, de 1.948, em seu artigo 25, que estabelece:

1.Toda a pessoa tem direito a um nível de vida suficiente para lhe assegurar e à sua família a saúde e o bem-estar, principalmente quanto à alimentação, ao vestuário, ao alojamento, à assistência médica e ainda quanto aos serviços sociais necessários, e tem direito à segurança no desemprego, na doença, na invalidez, na viuvez, na velhice ou noutros casos de perda de meios de subsistência por circunstâncias independentes da sua vontade. 2.A maternidade e a infância têm direito a ajuda e a

\footnotetext{
${ }^{60}$ SARLET, Ingo. Op. cit. p. 29-74
} 
assistência especiais. Todas as crianças, nascidas dentro ou fora do matrimônio, gozam da mesma proteção social.

Assim como os direitos fundamentais possuem características triviais, o mínimo existencial, por corresponder ao núcleo essencial de direitos fundamentais, também as possui. A principal característica ou até qualidade é a vedação ao retrocesso desse núcleo de direitos subjetivos elementares. Significa dizer que a cláusula de vedação ao retrocesso impede que sejam desconstituídas as conquistas já alcançadas pela sociedade. Garante, pois, à sociedade que o Estado irá cumprir com suas obrigações prestacionais, em relação à efetivação desses direitos sociais, que, uma vez concretizados, não podem ser reduzidos ou suprimidos pelo Estado, sob pena de violação à Constituição Federal.

\section{VI.III A NÃO APLICAÇÃO DA TEORIA DA RESERVA DO POSSÍVEL PELA JURISPRUDÊNCIA DOS TRIBUNAIS BRASILEIROS, QUANDO HOUVER PREJUÍZO OU LIMITAÇÃO DO NÚCLEO BÁSICO DOS DIREITOS QUE COMPÕEM O MÍNIMO EXISTENCIAL}

Como dito, a Constituição Federal contemporânea, no contexto do neoconstitucionalismo, deve ser enxergada como o primordial instrumento de direção e efetivação de políticas públicas, já que traz como fim último do Estado o bem-estar social e a proteção do indivíduo. Suas normas programáticas vinculam e devem dirigir a ação dos três Poderes, afinal, se está diante de uma Constituição Dirigente, da qual a Constituição atual é espécie.

Contudo, não há dúvidas de que a sociedade brasileira vive a falta de efetivação de tais normas que implementam programas de ação e norteiam a atuação do Poder Público. Mesmo que se trate de uma constituição nominal, dotada de força normativa, o Estado brasileiro não cumpre seu papel de fornecer o mínimo para o bom desenvolvimento de seus cidadãos, deixando 
à margem grande parte da população.

No Brasil, a teoria é mais admirável que a prática.

Não se trata, como muitos defendem, de violação ao princípio da separação dos Poderes. O Poder Judiciário, quando profere decisão que compele o Poder Executivo a fornecer medicamentos, tratamentos médicos e vagas em creches e escolas de ensino fundamental, não está fazendo nada de diferente da sua finalidade de exercer a função jurisdicional.

A propósito:

Nesse passo, a jurisdição constitucional deve ser compreendida como uma função responsável pela remoção e solução dos conflitos de natureza constitucional, enquanto a jurisdição ordinária cuidaria de todos os demais conflitos, ostentando uma natureza residual. Para nós, a matéria de natureza constitucional é aquela que tem por parâmetro imediato a defesa da Constituição, abrangendo propriamente a atividade de fiscalização da constitucionalidade dos atos e omissões do poder público, os conflitos de atribuições entre órgãos constitucionais e entidades políticas da Federação, além da proteção dos direitos fundamentais ${ }^{61}$.

Portanto, o posicionamento que os Tribunais brasileiros têm adotado é o e não aplicação da teoria da reserva do possível sempre que houver prejuízo ou limitação do núcleo básico dos direitos que compõem o mínimo existencial. E não poderia ser diferente, já que esse núcleo essencial guarda intrínseca relação com os direitos fundamentais e a dignidade da pessoa humana, compondo direitos subjetivos intrínsecos ao indivíduo, motivo pelo qual tem sido protegido de forma uniforme em todas as instâncias.

Este é, inclusive, o entendimento consolidado na Suprema Corte nos julgados que corroboram a tese defendida:

${ }^{61}$ JR, Dirley da Cunha. Op. cit. p.891-892 
E $\mathrm{m}$ e $\mathrm{n}$ t a: ampliação e melhoria no atendimento de gestantes em maternidades estaduais - Dever estatal de assistência materno-infantil resultante de norma constitucional - obrigação jurídico- -constitucional que se impõe ao poder público, inclusive aos estados-membros configuração, no caso, de típica hipótese de omissão inconstitucional imputável ao estado-membro - desrespeito à constituição provocado por inércia estatal (RTJ 183/818-819) - comportamento que transgride a autoridade da lei fundamental da república (RTJ 185/794-796) - a questão da reserva do possível: reconhecimento de sua inaplicabilidade, sempre que a invocação dessa cláusula puder comprometer o núcleo básico que qualifica o mínimo existencial (RTJ 200/191-197) - o papel do poder judiciário na implementação de políticas públicas instituídas pela constituição e não efetivadas pelo poder público - a fórmula da reserva do possível na perspectiva da teoria dos custos dos direitos: impossibilidade de sua invocação para legitimar o injusto inadimplemento de deveres estatais de prestação constitucionalmente impostos ao estado - a teoria da "restrição das restrições" (ou da "limitação das limitações") - caráter cogente e vinculante das normas constitucionais, inclusive daquelas de conteúdo programático, que veiculam diretrizes de políticas públicas, especialmente na área da saúde (CF, arts. 196, 197 e 227) - a questão das "escolhas trágicas" - a colmatação de omissões inconstitucionais como necessidade institucional fundada em comportamento afirmativo dos juízes e tribunais e de que resulta uma positiva criação jurisprudencial do direito controle jurisdicional de legitimidade da omissão do estado: atividade de fiscalização judicial que se justifica pela necessidade de observância de certos parâmetros constitucionais (proibição de retrocesso social, proteção ao mínimo existencial, vedação da proteção insuficiente e proibição de excesso) - doutrina - precedentes do supremo tribunal federal em tema de implementação de políticas públicas delineadas na constituição da república (RTJ 174/687 - RTJ 175/1212-1213 - RTJ 199/1219-1220) - possibilidade jurídico-processual de utilização das 
"astreintes" (CPC, art. 461, $5^{\circ}$ ) como meio coercitivo indireto - existência, no caso em exame, de relevante interesse social - ação civil pública: instrumento processual adequado à proteção jurisdicional de direitos revestidos de metaindividualidade - legitimação ativa do ministério público (CF, art. 129, III) - a função institucional do ministério público como "defensor do povo" (CF, art. 129, II) - doutrina - precedentes recurso de agravo improvido. (grifou-se) ${ }^{62}$.

E m e n t a: Recurso Extraordinário com agravo (Lei $n^{\circ}$ 12.322/2010) manutenção de rede de assistência à saúde da criança e do adolescente dever estatal resultante de norma constitucional - configuração, no caso, de típica hipótese de omissão inconstitucional imputável ao município desrespeito à constituição provocado por inércia estatal (RTJ 183/818819) - comportamento que transgride a autoridade da lei fundamental da república (RTJ 185/794-796) - a questão da reserva do possível: reconhecimento de sua inaplicabilidade, sempre que a invocação dessa cláusula puder comprometer o núcleo básico que qualifica o mínimo existencial (RTJ 200/191-197) - o papel do poder judiciário na implementação de políticas públicas instituídas pela constituição e não efetivadas pelo poder público - a fórmula da reserva do possível na perspectiva da teoria dos custos dos direitos: impossibilidade de sua invocação para legitimar o injusto inadimplemento de deveres estatais de prestação constitucionalmente impostos ao poder público - a teoria da "restrição das restrições" (ou da "limitação das limitações") - caráter cogente e vinculante das normas constitucionais, inclusive daquelas de conteúdo programático, que veiculam diretrizes de políticas públicas, especialmente na área da saúde (CF, arts. $6^{\circ}, 196$ e 197) - a questão das "escolhas trágicas" - a colmatação de omissões inconstitucionais como necessidade institucional fundada em comportamento afirmativo dos juízes e tribunais e de que resulta uma positiva criação jurisprudencial

${ }^{62}$ RE 581352 agr, relator(a): min. Celso de Mello, segunda turma, julgado em 29/10/2013, acórdão eletrônico DJE-230 divulg 21-11-2013 public 22-11-2013 
do direito - controle jurisdicional de legitimidade da omissão do poder público: atividade de fiscalização judicial que se justifica pela necessidade de observância de certos parâmetros constitucionais (proibição de retrocesso social, proteção ao mínimo existencial, vedação da proteção insuficiente e proibição de excesso) - doutrina - precedentes do supremo tribunal federal em tema de implementação de políticas públicas delineadas na Constituição da República (RTJ 174/687 - RTJ 175/1212-1213 - RTJ 199/1219-1220) - existência, no caso em exame, de relevante interesse social - recurso de agravo improvido. (grifou-se) ${ }^{63}$.

${ }^{63}$ ARE 745745 agr, relator(a): min. Celso de Mello, segunda turma, julgado em 02/12/2014, processo eletrônico DJE-250 divulg 18-12-2014 public 19-12-2014 


\section{CONCLUSÃO:}

O Neoconstitucionalismo, dito de forma sucinta, trata de uma nova visão do Direito Constitucional, pós-positivismo jurídico, que busca limitar a atuação do Estado e colocar o indivíduo, fim último deste, em evidência e protagonismo, haja vista a dignidade da pessoa humana, valor máximo das constituições contemporâneas. Passa-se, assim, a valorizar a carga axiológica dos princípios do Direito, mandamentos de otimização ${ }^{64}$, e trazer uma Constituição que seja uma Constituição Jurídica ${ }^{65}$ que se debruce sobre as questões de relevo social, em respeito aos direitos fundamentais, dotada de força normativa.

Ora, se esse propósito deve ser seguido por todos os Poderes estatais, como poderia, então, o Poder Judiciário deixar de proferir decisões que compelem o Poder Executivo a fornecer medicamentos, tratamentos médicos e vagas em creches e escolas de ensino fundamental, se se tratam de direitos subjetivos dos cidadãos brasileiros?

Não é admissível que a interpretação acerca das normas constitucionais programáticas seja no sentido de definição como meros conselhos dados pelo Poder Constituinte originário aos Poderes Executivo e Legislativo e Judiciário, ou como programas políticos que deveriam inspirar a atuação do legislador, mas que não podiam ser invocados perante o Judiciário, na defesa de direitos ${ }^{66}$, faltando-lhes a qualidade da eficácia.

Como reforçado durante todo o trabalho, é imperativo que se veja as normas constitucionais programáticas como normas que tratam de direitos sociais e, por isso, imprescindíveis que sejam aplicadas e, eficazes, para que

\footnotetext{
${ }^{64}$ R. Alexy, Teoria dos direitos fundamentais, p. 90-91. Trad. de Virgílio Afonso da Silva. SP, Malheiros, 2008.

${ }^{65}$ HESSE, Konrad, A Força Normativa da Constituição. Trad. de Gilmar Ferreira Mendes. 2009. Ed. 1'. Sérgio Antônio Fabris Editora.

${ }^{66}$ Sarmento, Daniel. (Artigo: Neoconstitucionalismo no Brasil. Riscos e possibilidades. 2009) ao citar Eduardo García de Enterría. La Constitución como Norma y el Tribunal Constitucional. 3. ed. Madrid: Civitas, 1985. p. 41
} 
se garanta a vida mais digna em sociedade, consubstanciada no princípio máximo da dignidade da pessoa humana.

De mesmo modo, configura abuso de direito do Poder Executivo se valer da teoria da reserva do possível para não cumprir com o seu dever de boa administração. Não é sequer imaginável não haver a efetivação desses direitos sociais fundamentais básicos ao desenvolvimento do indivíduo, pela alegada falta de verba orçamentária, quando se vive em um contexto de diversos escândalos políticos em que bilhões são desviados para as mãos de grande parcela dos governantes brasileiros.

A judicialização de políticas públicas, por alguns doutrinadores tratada de forma negativa ou como a sobreposição do Poder Judiciário sobre os demais Poderes, se torna, pela análise exposta, imprescindível para a garantia dos direitos fundamentais e do exercício da democracia, que apenas exerce sua função típica de, quando provocado, dirimir a lide. Ademais, é inegável que a maior atuação do Poder Judiciário para a garantia e efetividade dos direitos fundamentais exercerá nos outros Poderes da federação maior investimento nas áreas sociais, diante das decisões judiciais desfavoráveis, impositivas e sancionatórias.

Frisa-se que não se busca defender, no presente trabalho, que o Estado seja um garantidor universal, situação essa que inviabilizaria a promoção das próprias políticas públicas. Tampouco pretende-se amparar causas que extrapolam os limites da razoabilidade, ou a ideia de que a teoria da reserva do possível é completamente inaplicável. O que se quer é demonstrar que os direitos sociais, triviais ao ser humano, como os direitos à saúde e à educação são, inegavelmente, direitos subjetivos dos cidadãos e compõem o mínimo existencial, devendo sim ser tratados como prioridade para o orçamento estatal. Diante de uma omissão estatal, por serem direitos subjetivos, deve, pois, o indivíduo buscar a tutela jurisdicional de seu direito, legitimado pela própria Constituição. 


\section{REFERÊNCIAS BIBLIOGRÁFICAS}

ALEXY, Robert, Teoria dos direitos fundamentais, p. 90-91. Trad. de Virgílio Afonso da Silva. SP, Malheiros, 2008.

BARROSO, Luís Roberto. O Direito Constitucional e a efetividade de suas normas: limites e possibilidade da Constituição brasileira. Editora Renovar. $8^{\text {a }}$ Ed. 2006.

BARROSO, Luís Roberto; OSÓRIO, Aline Rezende Peres. "Sabe com quem está falando?": Algumas notas sobre o princípio da igualdade no Brasil contemporâneo. Texto-base da apresentação no Seminário en Latinoamérica de Teoría Constitucional y Política" - SELA, ocorrido entre 11 e 14 de junho de 2014, organizado pela YALE Law School. Disponível em: http://www.luisrobertobarroso.com.br/wpcontent/themes/LRB/pdf/SELA_Yale_palestra_igualdade_versao_fina.pdf (acesso em: 05/09/2017).

BOLSA FAMÍLIA - programas sociais, disponibilizado em http://www.caixa.gov.br/programas-sociais/bolsafamilia/Paginas/default.aspx (acesso 01/11/2017)

BVerfGE 33, 303, de 1973. Caso alemão paradigma Numerus Clausus I, julgado pelo Tribunal Constitucional Federal da Alemanha. Tradução livre. http://www.servat.unibe.ch/dfr/bv033303.html (acesso em 29/10/2017)

CANOTILHO, José Joaquim Gomes. Constituição dirigente e vinculação do legislador: contributo para a compreensão das normas constitucionais programáticas. Coimbra. 1982.

CANOTILHO, José Joaquim Gomes. Direito Constitucional e Teoria da Constituição. Almedina. $7^{a}$ Ed. 1993.

CONSTITUIÇÃO da República Federal da Alemanha, disponibilizada em http://www.brasil.diplo.de/contentblob/3160404/Daten/1330556/Gundgeset z_pt.pdf. (acesso em 27/10/2017)

CONSTITUIÇÃO da República Federativa do Brasil, disponibilizada em http://www.planalto.gov.br/ccivil_03/Constituicao/ConstituicaoCompilado. $\underline{\text { htm }}$ (acesso em 01/11/2017)

CRIZAFULLI, Vezio Stato, popolo, governo - Illusioni e desilusioniconstituzionali, 1985. p.64-67 (tradução livre) 
DE MELLO, Celso Antônio Bandeira. Eficácia das normas Oconstitucionais sobre a Justiça Social, Revista de Direito Social $\mathrm{n}^{\mathrm{o}} 7$

DI PIETRO, Maria Sylvia Zanella. Direito Administrativo. 27. Ed. Atlas S.A. 2014

DINIZ, Maria Helena, Norma constitucional e seus efeitos. Editora Saraiva. 2009.

HESSE, Konrad, A Força Normativa da Constituição. Tradução de Gilmar Ferreira Mendes. 2009. Ed. 1 ${ }^{\text {a }}$. Sérgio Antônio Fabris Editora.

HESSE, Konrad. Elementos de Direito Constitucional da República Federal da Alemanha. Trad. Luís Afonso Heck, Porto Alegre. Sérgio Antônio Fabris, 1998.

IBGE, países - Alemanha, disponibilizado em https://paises.ibge.gov.br/\#/pt/pais/alemanha/info/economia (acesso em 30/10/2017)

IBGE, países - $\quad$ Brasil, disponibilizado em https://paises.ibge.gov.br/\#/pt/pais/brasil/info/economia (acesso em $30 / 10 / 2017)$

JR. Dirley da Cunha, Curso de Direito Constitucional. 2015. 9ª Ed. Editora Juspodvim.

KELSEN, Hans. Teoria Pura do Direito. 1998. Martins Fontes Editora.

LENZA, Pedro. Direito Constitucional Esquematizado. $18^{\circ}$ Ed. 2004. Editora Saraiva.

LOEWENSTEIN, Karl. Teoria de la Constitución. 2. ed. Barcelona: Ariel, 1976

ROCHA, Cármen Lúcia Antunes. Palestra. Texto publicado na edição 252 da Revista de Direito Administrativo: http://www.editoraforum.com.br/ef/index.php/noticias/dignidade-dapessoa-humana-e-o-minimo-existencial/ (acesso em: 30/10/2017) 
SARLET, Ingo. Dignidade (da pessoa) humana, mínimo existencial e justiça constitucional: algumas aproximações e alguns desafios. Revista do CEJUR/TJSC: Prestação Jurisdicional, v. 1, nº 1, p. 29-44, dez. 2013

SARLET, Ingo. Os Direitos Fundamentai sociais na Constituição de 1988. Revista Diálogo Jurídico. Ano 1. Vol. 1. n 1. Abril de 2001. Salvador.

SARMENTO, Daniel. A Proteção Judicial dos Direitos Sociais: Alguns Parâmetros Ético-Jurídicos. 2008.

SARMENTO, Daniel. Artigo: Neoconstitucionalismo no Brasil. Riscos e possibilidades. 2009.

SILVA, José Afonso da. Aplicabilidade das normas constitucionais. Editora Malheiros. 8 Ed. 2.012

STF. AI 842740 Agr. Min. Rosa weber, primeira turma, julgado em 9.4.2014, acórdão eletrônico DJE-082 divulg 30-04-2014 public 2.5.2014

STF. ARE 727864 Agr, Min. Celso de Mello, segunda turma, julgado em 4.11.2014, acórdão eletrônico DJE-223 divulg 12.11.2014 public 13.11.2014

STF. RE 657718 RG, Min. Marco Aurélio, Julgado Em 17.11.2011, Acórdão Eletrônico Dje-051 Divulg 9.3.2012 Public 12.3.2012 Republicação: Dje092 Divulg 10.5.2012 Public 11.5.2012

STF. 761 Agr, Min. Ricardo Lewandowski (Presidente), Tribunal Pleno, Julgado Em 7.5.2015, Processo Eletrônico Dje-101 Divulg 20.5.2015 Public 29.5.2015

STF. Re 581.488, Min. Dias Toffoli, Tribunal Pleno, Julgado Em 3.12.2015, Acórdão Eletrônico Repercussão Geral - Mérito Dje-065 Divulg 7.4.2016 Public 8.4.2016

TJRJ, AI 0037722-83.2011.8.19.0000. Teresa De Andrade Castro Neves Sexta Câmara Cível. Data De Julgamento: 8.2.2012.

STF. ARE 639337 Agr, Min. Celso De Mello, Segunda Turma, Julgado Em 23.8.2011, Dje-177 Divulg 14.9.2011 Public 15.9.2011 
TORRES, Ricardo Lobo. O Mínimo Existencial e os Direitos Fundamentais.

Revista de Direito Administrativo, RJ, (42) 1990. p. 69 a 75. 


\section{CASOS APRESENTADOS À BANCA NA DEFESA}

\section{Pesquisa jurisprudencial do TJRJ sobre o pleito de transporte escolar para viabilizar o acesso de deficiente físico e neurológico à educação:}

0010293-31.2013.8.19.0014 - APELAÇÃO / REEXAME NECESSÁRIO. Ementa. DENISE LEVY TREDLER - VIGÉSIMA PRIMEIRA CÂMARA CÍVEL. AGRAVO INOMINADO EM APELAÇÃO/REEXAME NECESSÁRIO. DIREITO CONSTITUCIONAL. RESPONSABILIDADE CIVIL FUNDADA NA GARANTIA CONSTITUCIONAL À SAÚDE. OBRIGAÇÃO DE FAZER. FORNECIMENTO DE MEDICAMENTOS, HIDROTERAPIA, CADEIRA DE RODAS E DE BANHO E TRANSPORTE ESCOLAR COM ACOMPANHAMENTO. ACESSO À EDUCAÇÃO E À SAÚDE. DIREITOS SOCIAIS FUNDAMENTAIS. Ilegitimidade passiva do Estado afastada. Fornecimento de transporte escolar gratuito, com acompanhamento, que se justifica pelas condições físicas da paciente, portadora de encefalopatia crônica não progressiva, tetraparesia espástica e epilepsia. Garantia constitucional de acesso à educação e à saúde. Incidência dos artigos 23, e inciso VII, do 208, ambos da Constituição Federal, segundo os quais é competência comum da União, dos Estados, do Distrito Federal e dos Municípios proporcionar os meios de acesso à cultura, à educação e à ciência, além de que o dever do Estado com a educação será efetivado mediante a garantia de atendimento ao educando, em todas as etapas da educação básica, por meio de programas suplementares de material didático escolar, transporte, alimentação e assistência à saúde. Responsabilidade solidária dos entes federativos na garantia do acesso integral à educação aos portadores de necessidades especiais, inclusive no que se refere ao fornecimento de transporte escolar. Limitações e dificuldades orçamentárias que não fornecem pretexto idôneo para negar o direito à vida e à dignidade da pessoa humana. Serviço de transporte escolar com acompanhamento, que deve ser fornecido, à autora, como maneira de dar efetividade plena ao seu direito constitucional à educação e, sobretudo, à sua dignidade como pessoa humana. Decisão agravada que merece pequena reforma, apenas para constar a necessidade de observância do disposto nos artigos 10, inciso VII e 11, inciso VI, ambos da Lei $\mathrm{n}^{\circ}$ 9.394/96, bem como para esclarecer que o transporte escolar deve se enquadrar no padrão disponibilizado pelo Estado, desde que este atenda às necessidades especiais da autora, que necessita, inclusive, de cadeiras de rodas para se locomover. Provimento parcial do recurso. Data de julgamento: 07/06/2016. Grifou-se.

II. Na jurisprudência do Tribunal Regional Federal da 5a colaciona-se decisões sobre a concessão de fornecimento de 
medicamentos por parte do Estado, que não estão incluídos na lista da ANVISA. O tema está sendo julgado em repercussão geral pelo Supremo Tribunal Federal:

AGRAVO DE INSTRUMENTO. ADMINISTRATIVO. FORNECIMENTO DE MEDICAMENTO. TERIPARATIDA (FORTEO). AUSÊNCIA DE COMPROVAÇÃO DE RISCO DE VIDA. AUSÊNCIA DE DEMONSTRAÇÃO DA EFETIVIDADE DO TRATAMENTO. AUSÊNCIA DE DEMONSTRAÇÃO DA IMPRESTABILIDADE DOS DEMAIS TRATAMENTOS FORNECIDOS PELO SUS. AGRAVO IMPROVIDO E EMBARGOS DE DECLARAÇÃO PREJUDICADOS. 1. As escolhas do Poder Público no âmbito das prestações de saúde somente podem ser afastadas quando se constate, mediante prova robusta, a excepcionalidade do caso e a ineficiência da política pública existente. 2 . Na hipótese dos autos verifica-se o quadro de paciente que foi diagnosticada como portadora de Osteoporose Grave (M80.0) e múltiplos colapsos vertebrais. Explana que já fora submetida a tratamento com bifosfonatos, que não demonstrou sucesso, tendo a doença se agravado, com colapsos vertebrais e dor. Em razão disso, o médico que a acompanha recomendou a utilização do fármaco TERIPARATIDA (Forteo), não disponibilizado pelo SUS. 3. A Nota Técnica NTRR 94/2014 demonstra a existência de dúvidas acerca dos benefícios do tratamento sob a condição clínica do paciente, demonstrando a não comprovação da superioridade do medicamento em detrimento dos tratamentos já disponibilizado pelos SUS. 4. Não há nos autos, menção de que a terapêutica solicitada seja decisiva para a garantia da vida da agravante, de modo a implicar no reconhecimento de situação excepcional a ensejar, em prol de pessoa determinada, o custeio pelo Estado de ação ou serviço de saúde distinto daqueles que constam das políticas do SUS. Ao contrário, a Nota Técnica em questão sugere que a prescrição do medicamento implicará apenas em algum benefício à saúde da recorrente. 5. Não há evidências nos autos de que o emprego do fármaco objeto da ação originária seja a única solução a fim de promover o tratamento da doença que acomete a demandante, ora agravante. Embora exista menção no laudo médico acerca da não efetividade de medicamentos disponibilizados pelo Sistema Único de Saúde, não se pode olvidar que as pesquisas realizadas sobre o fármaco em questão atestam pela não comprovação de que tratamento seja mais efetivo do que os já fornecidos pelo Poder Público. 6. Agravo de instrumento improvido e embargos de declaração prejudicados. (PROCESSO: 08020745620164050000, AG/SE, DESEMBARGADOR FEDERAL EDÍLSON NOBRE, $4^{\mathrm{a}}$ Turma, JULGAMENTO: 16/06/2016). Grifou-se. 
AGRAVO DE INSTRUMENTO. ADMINISTRATIVO. FORNECIMENTO DE MEDICAMENTO. VIMIZIM(r) (ELOSULFASE ALFA). AUSÊNCIA DE AVALIAÇÃO PELA CONITEC. AUSÊNCIA DE COMPROVAÇÃO DE RISCO DE VIDA. EXISTÊNCIA DE TERAPÊUTICAS DISPONIBILIZADAS PELO SUS PARA O TRATAMENTO DA DOENÇA. AGRAVO IMPROVIDO. 1. As escolhas do Poder Público no âmbito das prestações de saúde somente podem ser afastadas quando se constate, mediante prova robusta, a excepcionalidade do caso e a ineficiência da política pública existente. 2 . Na hipótese dos autos verificase o quadro de paciente que foi diagnosticada como portadora de enfermidade genética grave, rara, hereditária, sem cura, progressiva e degenerativa, denominada MUCOPOLISSACARIDOSE TIPO IV (MPS IV), ou Síndrome de Morquio. Ante tal quadro, o médico que a assiste prescreveu o medicamento VIMIZIM(r) (ELOSULFASE ALFA), o qual não é integrante da lista de fármacos disponibilizados pelo SUS. 3. Apesar de o medicamento ser registrado na ANVISA, não fora avaliado pela CONITEC para integrar a lista de medicamentos disponibilizados pelo SUS. Ademais o medicamento fora analisado e não recomendado por países que possuem sistema público de saúde semelhantes ao do Brasil, quais sejam a Austrália e o Canadá. 4. Não há nos autos, menção de que a terapêutica solicitada seja decisiva para a garantia da vida da agravante, nem que as demais terapêuticas disponibilizadas pelo SUS sejam imprestáveis para o caso, de modo a implicar no reconhecimento de situação excepcional a ensejar, em prol de pessoa determinada, o custeio pelo Estado de ação ou serviço de saúde distinto daqueles que constam das políticas do SUS. 5. Agravo de instrumento a que se nega provimento, julgando prejudicado $\mathrm{o}$ pedido de reconsideração e suspendendo imediatamente a eficácia da medida liminar concedida. (PROCESSO: 08062440820154050000, AG/SE, DESEMBARGADOR FEDERAL EDÍLSON NOBRE, $4^{a}$ Turma, JULGAMENTO: 29/01/2016). Grifou-se.

III. Pesquisa realizada, também no site do Tribunal Regional Federal da 5a região, sobre a possibilidade de o Estado ser compelido a custear cirurgias realizadas no exterior:

Informativo $\mathrm{n}^{\mathrm{o}}$ 0146. Período: 9 a 13 de setembro de 2002. SEGUNDA TURMA. TRATAMENTO MÉDICO. EXTERIOR. REEMBOLSO. Constatada a forma de leucemia gravíssima que acometia a recémnascida filha do autor, que necessitava, com urgência, de transplante de medula óssea, sua família procurou o único hospital em território nacional habilitado, àquela época, a realizar tal intervenção. Sucede que, 
pela grande demanda e longa lista de espera, foram aconselhados a buscar tratamento no exterior, pois não se poderia, aqui, realizar a cirurgia a tempo de salvá-la. Buscaram, então, auxílio financeiro junto ao Inamps, que se quedou silente. Com parte dos recursos necessários obtidos em outras entidades, contraíram empréstimos e venderam bens, conseguindo custear, assim, a intervenção. Infelizmente, mesmo após a operação, a menina não resistiu e veio a falecer, sendo interposta ação de cobrança com a finalidade de reaver os valores gastos, o que resultou na condenação da União, sucessora do Inamps. No REsp, a União sustenta que, naquele momento, por regulamento, a concessão desse tipo de auxílio estaria suspensa. Prosseguindo o julgamento, após voto de desempate, a Turma, por maioria, não conheceu do recurso, ao fundamento de que, se estavam esgotadas no país todas as possibilidades do tratamento, urgente e imprescindível como sobejamente provado, e diante do silêncio da autoridade competente, a exigência de prévia autorização para reembolso resta afastada, quanto mais se o art. 60 do Dec. n. 89.312/1984 a excepciona em casos de força maior. Admitir sustar todo o custeio desses tratamentos excepcionais e urgentes é negar o direito fundamental à saúde e à vida, sentenciando o paciente à morte. $\mathrm{O}$ Min. Franciulli Netto aduziu que, diante das peculiaridades, o silêncio do Inamps poderia ser entendido como aquiescência e que, defronte de direito fundamental, cai por terra qualquer outra justificativa de natureza técnica ou burocrática. Precedentes citados: RMS 11.183-PR, DJ 4/9/2000; MS 6.002DF, DJ 14/2/2000, e REsp 212.346-RJ, DJ 4/2/2002. REsp 338.373-PR, Rel. originária Min. Eliana Calmon, Rel. para acórdão Min. Laurita Vaz, julgado em 10/9/2002. Grifou-se.

PROCESSUAL CIVIL E ADMINISTRATIVO. AGRAVO INTERPOSTO CONTRA DECISÃO (DE RECONSIDERAÇÃO) INDEFERITÓRIA DE PEDIDO SUSPENSIVO DOS EFEITOS DA SENTENÇA PROLATADA EM AÇÃO CIVIL PÚBLICA. LEI No 8.437/92. MP N ${ }^{\circ}$ 2.180-35/2001. CRIANÇA PORTADORA DE MAPLE SYRUP URINE DISEASE (MSUD) OU DOENÇA DE URINA DO XAROPE DE BORDO (DUXB). DEFICIÊNCIA NA METABOLIZAÇÃO DE AMINOÁCIDOS. TRANSPLANTE DE FÍGADO NOS ESTADOS UNIDOS DA AMÉRICA. DIREITO CONSTITUCIONAL À SAÚDE. FUNDAMENTALIDADE. INEXISTÊNCIA DE INSTITUIÇÃO BRASILEIRA APTA A REALIZAR O PROCEDIMENTO CIRÚRGICO COMPLETO COM MANEJO METABÓLICO. CONSTATAÇÃO FUNDADA NAS INFORMAÇÕES PRESTADAS PELA ÚNICA UNIDADE DE SAÚDE INDICADA PELO ENTE PÚBLICO COMO CAPACITADA À CIRURGIA. DISTINTIVO. 1. Agravo interposto contra decisão da presidência que, em juízo de reconsideração, indeferiu o pedido de suspensão dos efeitos da sentença, que, 
prolatada em sede de ação civil pública, determinou à União a adoção das providências necessárias à viabilização do tratamento de menor nos Estados Unidos da América, financiando específico transplante hepático e custeando deslocamento e estadia da criança e de um dos pais. 2. A concessão de suspensão de liminar ou de sentença, nos termos do art. 4o, da Lei $\mathrm{n}^{\circ}$ 8.437/92, com as alterações da MP $\mathrm{n}^{\mathrm{o}}$ 2.180-35/2001, apenas é admitida em caso de manifesto interesse público ou de flagrante ilegitimidade e para impedir grave lesão à ordem, à saúde, à segurança e à economia públicas, cabendo ao ente postulante a demonstração inequívoca dessas condições. Destarte, trata-se de medida excepcional, de procedimento sumário e de cognição incompleta, justificada pela seriedade das conseqüências derivadas, no âmbito da qual não se efetua exame de mérito em relação à lide originária, mas apenas uma aferição da plausibilidade das razões deduzidas pelo requerente, associada à verificação da possibilidade lesiva das esferas significativas enumeradas na norma jurídica legal (ordem pública, saúde pública, segurança pública e economia pública), com a perscrutação da urgência da providência requestada. Em síntese, deve-se lançar olhos ao perfazimento dos pressupostos específicos - o fumus boni juris e o periculum in mora -, particularizados esses requisitos, ainda mais, no instrumento, pela delimitação do universo a ser considerado diante da mácula expressiva a ser obstada. "Essa orientação, contudo, não deixa de admitir um exercício mínimo de deliberação do mérito, sobretudo por ser medida de contracautela, vinculada aos pressupostos de plausibilidade jurídica e do perigo da demora, que devem estar presentes para a concessão das liminares" (trecho do voto do Ministro Edson Vidigal, no AgRg na Suspensão de Liminar n ${ }^{\circ}$ 57/DF, j. em 01.07.2004, publ. em DJ de 06.09.2004). 3. Nos termos da Norma Constitucional (arts. 5o, 6o, 196 e 227), o direito à saúde é marcado por sua "fundamentalidade", considerando-se mesmo que sua garantia é expressão de resguardo da própria vida, maior bem de todos, do qual os demais direitos extraem sentido. Analisando $o$ conceito de "fundamentalidade", J J Gomes CANOTILHO concebe-o sob duas perspectivas: a "fundamentalidade formal", correspondente à constitucionalização, à localização de direitos reputados fundamentais no ápice da pirâmide normativa, com as consequiências, desse fato, derivadas - demarcação das possibilidades do ordenamento jurídico e vinculatividade dos poderes públicos -, e a "fundamentalidade material", identificadora dos direitos fundamentais a partir do seu conteúdo "constitutivo das estruturas básicas do Estado e da sociedade", permissiva do reconhecimento de outros direitos não expressamente tipificados no rol constitucional, mas equiparáveis em dignidade e relevância aos direitos formalmente constitucionais ("norma de fattispecie aberta"). Em ambas as visões, exsurge a magnitude da 
essencialidade, embora seja patente a maior significância compreensiva da segunda. "No qualificativo fundamentais acha-se a indicação de que se trata de situações jurídicas sem as quais a pessoa humana não se realiza, não convive e, às vezes, nem mesmo sobrevive; fundamentais do homem no sentido de que todos, por igual, devem ser, não apenas formalmente reconhecidos, mas concreta e materialmente efetivados" (José Afonso da Silva). Os direitos fundamentais cumprem, nessa contextura, determinadas funções: exigem prestações do Estado, protegem diante do poder público e de terceiros, fomentam a paridade entre os indivíduos, designam os alicerces sobre os quais se constrói e se orienta o ordenamento jurídico ("eficácia irradiante"). Têm força, ao mesmo tempo, por assim dizer, de princípio e de regra. 4. Segundo relato médico, o menor é portador de uma doença chamada Maple Syrup Urine Disease (MSUD) ou Doença de Urina do Xarope de Bordo (DUXB), que se caracteriza pela deficiência na metabolização dos aminoácidos valina, isoleucina e leucina, já tendo passado, em razão da enfermidade, algum tempo na UTI pediátrica, com piora do quadro de convulsões e do estado comatoso. Também segundo a descrição médica, a despeito do relativo bom controle bioquímico, a criança já apresenta retardo do desenvolvimento neuropsicomotor e convulsões controladas com o uso de anticonvulsionante, de modo que o transplante apresenta-se como alternativa de tratamento viável e que pode resultar na correção definitiva da condição de saúde. Em continuação, o médico destaca que a realização de transplantes hepáticos em crianças no Brasil é realidade já estabelecida, com referenciais profissionais importantes, mas que a particularidade da doença que acometeu a criança faz com que o tratamento que a ela deva ser aplicado se afaste da modalidade comum de transplante de fígado. Sobre isso, registra: "De um modo geral os procedimentos envolvidos no transplante de fígado de um paciente com doença metabólica não diferem daquele de outros pacientes não-metabólicos. A diferença fundamental é que na DUXB a descompensação metabólica pode ocorrer a qualquer momento tendo potencial de gerar danos neurológicos e até mesmo colocar o paciente em situação de risco de óbito". Assim, o profissional médico destaca que o grande impedimento à execução do procedimento no Brasil é a ausência de "experiência no manejo metabólico desse tipo de paciente". Em outros termos, para o tipo de doença da criança, exige-se, como tratamento, o transplante de fígado com manejo metabólico, sendo que no Brasil apenas se pode realizar o transplante de fígado, não havendo instituições capacitadas ao maneio do metabolismo. Esse "manejo metabólico" requer a existência de um protocolo que compreenda "medidas pré, trans e pós cirúrgicas", bem como a disponibilidade de equipamentos de dosagem rápida de aminoácidos com funcionamento vinte e quatro horas, a presença de profissional treinado na área de interpretação dos resultados, a disponibilidade de uma solução 
parenteral especial para descompensação e o conhecimento na sua utilização. É importante realçar que o médico, geneticista clínico do Hospital das Clínicas de Porto Alegre, ao indicar, como mais racional e seguro, que o paciente se submetesse ao tratamento no exterior, reconheceu, explicita e responsavelmente, a inabilidade para a realização do procedimento em território nacional. 5. A União se insurge contra a pretensão de realização do transplante hepático específico nos EUA, afirmando que existe instituição de saúde brasileira capacitada à realização do procedimento, qual seja o Hospital das Clínicas de Porto Alegre, da Universidade Federal do Rio Grande do Sul. 6. $O$ único hospital que a União indica, como capacitado à realização do procedimento médico, assevera que nunca realizou esse tipo de transplante; que não tem sequer um protocolo específico; que seria necessário mandar um membro da equipe médica para ser treinado no exterior; que não possui o indispensável equipamento, com funcionamento vinte e quatro horas, para o monitoramento de aminoácidos da criança (exceto um muito velho que atende outras demandas); e que não consegue obter nem mesmo a cotação do custo da solução parenteral de controle. Assim, não restaram atendidas as exigências do art. 9o, do Decreto $\mathrm{n}^{\circ}$ 2.268/97, que regulamentou a Lei ${ }^{\circ}$ 9.434/97. 7. É evidente a todos os olhos, ainda que não versados na área de saúde, que não é possível estabelecer um protocolo adequado para uma doença com essas características em 60 (sessenta) dias, bem como que uma semana de treinamento no exterior para o manejo de aminoácidos não é suficiente para dar a capacitação necessária e que a aquisição da máquina exigirá procedimento administrativo demorado. De igual modo, se não se consegue nem mesmo cotar a solução parenteral, o que se dirá de sua manipulação, destacando-se que a prescrição incorreta pode levar ao óbito. 8. A urgência na realização do procedimento médico é patente, em vista de que, quanto mais cedo for implementado, menores serão as sérias sequielas. Não passam despercebidas, nesse ponto, as crises de descompensação metabólica pelas quais tem passado a criança e que afetam a sua integridade, causando-lhe retardo no desenvolvimento neuropsicomotor. 9. Outro aspecto destacado pela União é que o valor do transplante pelo SUS seria de $\mathbf{R} \mathbf{\$} \mathbf{5 2 . 0 0 0 , 0 0}$ (cinqüenta e dois mil reais), enquanto o mesmo tratamento no exterior estaria orçado em U\$ 200,000 (duzentos mil dólares). Contudo, observa-se dos documentos juntados que o menor já conseguiu um desconto da instituição médica de $45 \%$, além de ter sido beneficiado com uma doação efetivada por uma fundação americana de U\$ 25,000 (vinte e cinco mil dólares), o que baixaria as despesas com o transplante para U\$ 75,000 (setenta e cinco mil dólares). Vem então, a União, e sustenta que os U\$ 75,000 não incluiriam as despesas associadas ao pós-operatório. Ocorre que essa assertiva também é válida para o preço que ela apresenta, porquanto nos $\mathrm{R} \$$ 
52.000,00 não estão incluídos os custos com o manejo metabólico, mesmo porque não se consegue sequer cotar a solução parenteral e ainda se fala na aquisição de equipamento e em treinamento de pessoal. 10. Maior ofensa à economia pública parece se materializar com a não realização do procedimento médico, de logo, em vista do tipo de alimentação (MSUD Maxamaid) de que necessita o menor e que faz com que os cofres públicos disponibilizem cerca de $R \$ 1.400,00$ a cada três dias, sendo esse o custo do fornecimento consideradas a unidade do medicamento e sua durabilidade. Sublinhe-se que a tentativa de controle da enfermidade, não realizado o transplante (que inclui etapas prévias e posteriores), é levada a efeito através do ministério dessa alimentação especial, de sorte que a ela o menor ficará vinculado por toda a vida ou até que sobrevier a morte. Assim, enquanto o Estado se recusa a financiar a cirurgia no exterior, continua arcando com as despesas de aquisição do suporte nutricional e o menor sofre crises de descompensação metabólica ocasionadas pela elevação dos aminoácidos que podem provocar retardo mental, coma e morte. De outro lado, procedendo-se ao transplante, a família assume o risco relacionado ao seu êxito, ao passo que o ente público se eximirá de custear a dieta especial com a recuperação da saúde da criança. 11 . Não há que se falar em fuga ao regime do precatório, característico das execuções contra a Fazenda Pública, quando se está diante de obrigação de fazer, evidenciada pelo caráter mandamental da sentença. 12. Pelo não provimento do agravo. (PROCESSO: 20050500004629202, AGRSL3556/02/CE, DESEMBARGADOR FEDERAL FRANCISCO CAVALCANTI, Presidência, JULGAMENTO: 08/06/2005, PUBLICAÇÃO: DJ 20/06/2005 - P. Grifou-se. 